\title{
In silico drug repurposing for the identification of potential candidate molecules against arboviruses infection
}

\author{
Diana Montes-Grajales $^{\mathrm{a}, *, 1}$, Henry Puerta-Guardo ${ }^{\mathrm{b}, 1}$, Diego A. Espinosa ${ }^{\mathrm{b}}$, Eva Harris ${ }^{\mathrm{b}}$, \\ William Caicedo-Torres ${ }^{\mathrm{c}}$, Jesus Olivero-Verbel ${ }^{\mathrm{a}}$, Esperanza Martínez-Romero ${ }^{\mathrm{d}}$ \\ ${ }^{a}$ Environmental and Computational Chemistry Group, School of Pharmaceutical Sciences, Zaragocilla Campus, University of Cartagena, Cartagena, 130015, Colombia \\ ${ }^{\mathrm{b}}$ Division of Infectious Diseases and Vaccinology, School of Public Health, University of California, Berkeley, Berkeley, CA, 94720-3370, USA \\ ${ }^{\mathrm{c}}$ Grupo de Investigación de Tecnologías Aplicadas y Sistemas de Información, School of Engineering, Universidad Tecnológica de Bolívar, Cartagena, 130010, Colombia \\ ${ }^{\mathrm{d}}$ Centro de Ciencias Genómicas, Universidad Nacional Autónoma de México, Cuernavaca-Morelos 565-A, Mexico
}

\section{A R T I C L E I N F O}

\section{Keywords:}

Dengue

Zika

Chikungunya

Virtual screening

Antiviral

Virus entry

\begin{abstract}
A B S T R A C T
Arboviral diseases caused by dengue (DENV), Zika (ZIKV) and chikungunya (CHIKV) viruses represent a major public health problem worldwide, especially in tropical areas where millions of infections occur every year. The aim of this research was to identify candidate molecules for the treatment of these diseases among the drugs currently available in the market, through in silico screening and subsequent in vitro evaluation with cell culture models of DENV and ZIKV infections. Numerous pharmaceutical compounds from antibiotics to chemotherapeutic agents presented high in silico binding affinity for the viral proteins, including ergotamine, antrafenine, natamycin, pranlukast, nilotinib, itraconazole, conivaptan and novobiocin. These five last compounds were tested in vitro, being pranlukast the one that exhibited the best antiviral activity. Further in vitro assays for this compound showed a significant inhibitory effect on DENV and ZIKV infection of human monocytic cells and human hepatocytes (Huh-7 cells) with potential abrogation of virus entry. Finally, intrinsic fluorescence analyses suggest that pranlukast may have some level of interaction with three viral proteins of DENV: envelope, capsid, and NS1. Due to its promising results, suitable accessibility in the market and reduced restrictions compared to other pharmaceuticals; the anti-asthmatic pranlukast is proposed as a drug candidate against DENV, ZIKV, and CHIKV, supporting further in vitro and in vivo assessment of the potential of this and other lead compounds that exhibited good affinity scores in silico as therapeutic agents or scaffolds for the development of new drugs against arboviral diseases.
\end{abstract}

\section{Introduction}

The incidence of dengue, Zika and chikungunya viral infections has grown dramatically around the world, becoming a global public health concern, with cases reported in more than 100,80 and 40 countries, respectively (Calvo et al., 2015; Gardner et al., 2018; Mayer et al., 2017; Villegas et al., 2018; Walker et al., 2014; World Health Organization, 2018, 2017, 2016). Several vaccine candidates have been evaluated in preclinical and clinical trials (Hallengärd et al., 2014; López-Camacho et al., 2018; Roy et al., 2014; Smalley et al., 2016). However, there are no licensed vaccines against Zika and chikungunya and there exists uniquely one registered vaccine against dengue, called Dengvaxia, which only confer partial immunity and has some safety warnings (Aguiar and Stollenwerk, 2018; Flasche et al., 2016; Guzman et al., 2013; Halstead, 2017; Scherwitzl et al., 2017; Whitehead and Subbarao, 2017). The absence of approved antiviral drugs to combat these diseases (Low et al., 2017; Tomlinson et al., 2009) and the increase in the endemic zone of the vectors due to the climate change and unplanned urbanization (Ebi and Nealon, 2016; Liu-Helmersson et al., 2016), evidence the need for the development of potent anti-dengue drugs.

Flaviviruses such as dengue (DENV) and Zika (ZIKV) (belonging to the Flaviviridae family), and alphaviruses such as chikungunya (CHIKV) (belonging to the Togaviridae family) are small, enveloped, singlestranded, positive-sense RNA viruses, transmitted primarily by Aedes spp. mosquitoes (Lazear et al., 2016; Weaver, 2014). As part of their viral replication cycle, DENV, ZIKV and CHIKV enter host cells via viral glycoprotein receptor-mediated endocytosis to use the machinery of the

\footnotetext{
* Corresponding author.

E-mail address: dmontesg@unicartagena.edu.co (D. Montes-Grajales).

${ }^{1}$ These authors contributed equally.
} 


\author{
Abbreviation \\ CHIKV chikungunya virus \\ CHIKV E1Envelope 1 \\ CHIKV E2Envelope 2 \\ CHIKV nsP2 Non-structural polyprotein 2 \\ DENV dengue virus \\ DENV-2 dengue virus type 2 \\ DENV-3 dengue virus type 3 \\ DENV C Capsid \\ DENV NS2B/NS3 Non-structural protein 2B/non-structural protein \\ 3 complex \\ DENV NS5 DENV non-structural protein 5 \\ DENV2 E DENV-2 virus envelope glycoprotein
}

DENV3 NS5 DENV-3 non-structural protein 5

FFA focus-forming assay

GlycAc glycine acid

NS3 non-structural protein-3

nsP2 nonstructural polyprotein 2

PDB Protein Data Bank

ZIKV Zika virus

ZIKV C Capsid protein from Zika Virus

ZIKV E Domain III of envelope protein

ZIKV MTase ZIKV MTase

ZIKV NS1 Zika virus non-structural protein 1

ZIKV NS2B/NS3 NS2B-NS3 protease

ZIKV NS3 NS3 protease

ZIKV NS5 NS5 RNA-dependent RNA polymerase (RdRP) infected cell to synthesize viral proteins and replicate their genome (Dai et al., 2016; Harrison, 2015; Marsh and Pelchen-Matthews, 1993; Más and Melero, 2013). The viral RNA genome encodes a single polyprotein containing three structural proteins incorporated into the virions (capsid (C), pre-membrane/membrane (prM/M) and envelope (E)), and seven non-structural proteins (NS1, NS2A, NS2B, NS3, NS4A, NS4B and NS5) that coordinates virus replication, assembly and modulation of host defense mechanisms. The molecular mechanism responsible for the development of disease (Eglen et al., 2000) is mediated by viral proteins, which constitute target molecules in drug development (Bekerman and Einav, 2015; Klumpp and Crépin, 2014; Liang et al., 2016). Therefore, the purpose of this research was to identify in silico candidate molecules among known pharmaceuticals with the potential to bind DENV, ZIKV and CHIKV proteins to help to prioritize compounds for in vitro an in vivo evaluation; with further in vitro antiviral activity assessment of five selected compounds. This drug repurposing (or repositioning) strategy was used to accelerate the discovery of safe and efficient treatments for patients (Abdulla et al., 2009; Bastos and Coelho, 2014; Langedijk, 2016; Ma et al., 2013; Mehndiratta et al., 2016; O'Connor and Roth, 2005; Pushpakom et al., 2018; J. Zhang et al., 2017).

\section{Methods}

\subsection{Viral proteins and ligands structures}

The crystallographic coordinates of DENV, ZIKV and CHIKV proteins, with suitable resolution for docking studies (on average $\leq 2.0 \AA$ ), were downloaded from Protein Data Bank (PDB) (http://www.rcsb. $\mathrm{org} /$ ) in $\mathrm{pdb}$ format, and prepared as described in our previous article (Montes-Grajales et al., 2016).

Small-molecule drug structures were obtained from the database of approved pharmaceuticals on DrugBank (http://www.drugbank.ca) as sdf files and converted to mol2 format using Open Babel (O'Boyle et al., 2011). The molecular structures were prepared using AutoDockTools 1.5.6 (Morris et al., 2009) by adding Kollman charges and polar hydrogen atoms and were saved in pdbqt files.

\subsection{Virtual screening protocol}

The virtual screening protocol was the same used by CabarcasMontalvo et al. (2016), which has been validated with experimental assays for DENV proteins, as well as for other datasets in our previous studies (Cabarcas-Montalvo et al., 2016; Montes-Grajales et al., 2016, 2013; Montes-Grajales and Olivero-Verbel, 2013). Blind docking technique was employed with the purpose of finding promising lead compounds in existing drugs to target DENV, ZIKV and CHIKV proteins according to their AutoDock Vina affinity score ( $\mathrm{kcal} / \mathrm{mol}$ ) (Trott and Olson, 2010). The settings used were: number of modes of 20, an energy range of 1.5 , and exhaustiveness equal to 20. Simulations were performed in triplicate, keeping the best pose for each run. Finally, average affinities for the best poses were taken as the final value.

Additionally, a heatmap was created using R (R Core Team, 2016) with the affinity scores between pharmaceuticals and viral proteins, by using the "heatmap.2" function included in the gplot library (Warnes et al., 2009). The range color was defined implementing RColorBrewer, assigning red from $-12.0 \mathrm{kcal} / \mathrm{mol}$ to $-7.0 \mathrm{kcal} / \mathrm{mol}$ (strong and moderate), white from $-7.0 \mathrm{kcal} / \mathrm{mol}$ to $-6.0 \mathrm{kcal} / \mathrm{mol}$ (weak), and blue to affinities greater than $-6.0 \mathrm{kcal} / \mathrm{mol}$.

\subsection{Evaluation of protein-ligand interactions}

The best pose of the small-molecule drugs with the best affinity scores for the tested viral proteins were isolated in AutoDock Tools 1.5.6 (Morris et al., 2009) from the AutoDock Vina docking resultant files and merged with the optimized protein structures in pdb format using Pymol (Seeliger and de Groot, 2010). Contact residues of these merged structures were analyzed with LigandScout 3.0 (Wolber and Langer, 2005), setting the interaction cutoff threshold to $7 \AA$ (MontesGrajales and Olivero-Verbel, 2013).

\subsection{Assessment of antiviral activity in DENV and ZIKV infection in vitro}

To assess the potential inhibitory effect of pranlukast, nilotinib, conivaptan, itraconazole, and novobiocin (Suppl. Table 1) on the infectivity of enveloped viruses, we performed experimental infections in vitro using a human monocytic cell line expressing the attachment factor DC-SIGN (U937-DC-SIGN), which is highly susceptible to DENV

Table 1

List of studied proteins.

\begin{tabular}{llll}
\hline Name & Abbreviation & PDB ID & Organism \\
\hline DENV-2 virus envelope glycoprotein & DENV2 E & 1OK8 & DENV \\
DENV Capsid & DENV C & 1R6R & DENV \\
DENV non-structural protein 2B/non- & DENV NS2B/NS3 & 2FOM & DENV \\
$\quad$ structural protein 3 complex & DENV NS5 & 2J7U & DENV \\
DENV non-structural protein 5 & DENV3 NS5 & 5JJS & DENV \\
DENV-3 non-structural protein 5 & ZIKV E & 5OMZ & ZIKV \\
ZIKV Domain III of envelope protein & ZIKV C & 5YGH & ZIKV \\
ZIKV Capsid Protein from Zika Virus & ZIKV MTase & 5WXB & ZIKV \\
ZIKV NS5 MTase & ZIKV NS1 & 5K6K & ZIKV \\
Zika virus non-structural protein 1 & ZIKV NS2B/NS3 & 5H4I & ZIKV \\
ZIKV NS2B-NS3 protease & ZIKV NS3 & 5YOD & ZIKV \\
ZIKV NS3 protease & ZIKV NS5 & 5WZ3 & ZIKV \\
ZIKV NS5 RNA-dependent RNA & & & \\
polymerase (RdRP) & CHIKV E1 & 3N40 & CHIKV \\
CHIKV envelope 1 & CHIKV E2 & 3N44 & CHIKV \\
CHIKV envelope 2 & CHIKV nsP2 & 3TRK & CHIKV \\
CHIKV non-structural polyprotein 2 & & &
\end{tabular}


Table 2

Small-molecule drugs with the best docking affinity scores $(\mathrm{kcal} / \mathrm{mol})$ for the studied DENV, ZIKV and CHIKV proteins.

\begin{tabular}{|c|c|c|c|}
\hline Name & CID & Description & $\begin{array}{l}\text { Docking affinity } \\
\text { (kcal/mol) }\end{array}$ \\
\hline \multicolumn{4}{|l|}{ DENV2 E } \\
\hline Ergotamine & 8223 & Vasoconstrictor & $-9.8 \pm 0.2$ \\
\hline Dihydroergotamine & 10531 & $\begin{array}{l}\text { Analgesic/ } \\
\text { vasoconstrictor }\end{array}$ & $-9.4 \pm 1.2$ \\
\hline Nilotinib & 644241 & Antineoplastic & $-9.3 \pm 0.1$ \\
\hline Antrafenine & 68723 & $\begin{array}{l}\text { Analgesic/ } \\
\text { antiinflammatory }\end{array}$ & $-9.3 \pm 0.5$ \\
\hline Gliquidone & 91610 & Hypoglycemic & $-9.1 \pm 0.2$ \\
\hline \multicolumn{4}{|l|}{ DENV C } \\
\hline Pranlukast & 4887 & Antiasthmatic & $-9.1 \pm 0.1$ \\
\hline Cabozantinib & 25102847 & Antineoplastic & $-8.9 \pm 0.0$ \\
\hline Ciclesonide & 6918155 & $\begin{array}{l}\text { Antiallergic/ } \\
\text { antiinflammatory }\end{array}$ & $-8.9 \pm 0.0$ \\
\hline Dihydroergotamine & 10531 & $\begin{array}{l}\text { Analgesic/ } \\
\text { vasoconstrictor }\end{array}$ & $-8.8 \pm 0.0$ \\
\hline Nilotinib & 644241 & Antineoplastic & $-8.8 \pm 0.0$ \\
\hline Zafirlukast & 5717 & Antiasthmatic & $-8.8 \pm 0.1$ \\
\hline $\begin{array}{l}\text { Nandrolone } \\
\text { phenpropionate }\end{array}$ & 229455 & Anabolic & $-8.8 \pm 0.2$ \\
\hline \multicolumn{4}{|c|}{ DENV NS2B/NS3 complex } \\
\hline Nilotinib & 644241 & Antineoplastic & $-10.6 \pm 0.2$ \\
\hline Imatinib & 5291 & Antineoplastic & $-10.2 \pm 0.1$ \\
\hline Regorafenib & 11167602 & Antineoplastic & $-10.1 \pm 0.2$ \\
\hline Ponatinib & 24826799 & Antineoplastic & $-10.1 \pm 0.2$ \\
\hline Eltrombopag & 66583167 & Antithrombocytopenic & $-9.5 \pm 0.0$ \\
\hline Sorafenib & 216239 & Antineoplastic & $-9.5 \pm 0.0$ \\
\hline \multicolumn{4}{|l|}{ DENV NS5 } \\
\hline Conivaptan & 151171 & Vasopressin antagonist & $-10.6 \pm 0.0$ \\
\hline Dutasteride & 6918296 & $\begin{array}{l}\text { Prostatic hypertrophy } \\
\text { agent }\end{array}$ & $-10.3 \pm 0.0$ \\
\hline Natamycin & 5284447 & Antifungal & $-9.9 \pm 0.0$ \\
\hline Tubocurarine & 6000 & Neuromuscular blocker & $-9.9 \pm 0.0$ \\
\hline Ergotamine & 8223 & Vasoconstrictor & $-9.7 \pm 0.2$ \\
\hline \multicolumn{4}{|l|}{ DENV3 NS5 } \\
\hline Conivaptan & 151171 & Vasopressin antagonist & $-11.4 \pm 0.0$ \\
\hline Ergotamine & 8223 & Vasoconstrictor & $-11.3 \pm 0.0$ \\
\hline Dihydroergotamine & 10531 & $\begin{array}{l}\text { Analgesic/ } \\
\text { vasoconstrictor }\end{array}$ & $-11.0 \pm 0.0$ \\
\hline Diosmin & 5281613 & Vasoconstrictor & $-11.0 \pm 0.0$ \\
\hline Irinotecan & 60838 & Antineoplastic & $-11.0 \pm 0.2$ \\
\hline \multicolumn{4}{|l|}{ ZIKVE } \\
\hline Ergotamine & 8223 & Vasoconstrictor & $-9.3 \pm 0.8$ \\
\hline Dihydroergotamine & 10531 & $\begin{array}{l}\text { Analgesic/ } \\
\text { vasoconstrictor }\end{array}$ & $-9.1 \pm 0.0$ \\
\hline Nilotinib & 644241 & Antineoplastic & $-9.1 \pm 0.1$ \\
\hline Lomitapide & 9853053 & Antilipemic & $-9.0 \pm 0.1$ \\
\hline Eltrombopag & 66583167 & Antithrombocytopenic & $-8.9 \pm 0.3$ \\
\hline Conivaptan & 151171 & Vasopressin antagonist & $-8.9 \pm 0.1$ \\
\hline Gliquidone & 91610 & Hypoglycemic & $-8.9 \pm 0.3$ \\
\hline \multicolumn{4}{|l|}{$Z I K V C$} \\
\hline Nilotinib & 644241 & Antineoplastic & $-8.9 \pm 0.2$ \\
\hline Dihydroergotamine & 10531 & $\begin{array}{l}\text { Analgesic/ } \\
\text { vasoconstrictor }\end{array}$ & $-8.9 \pm 0.1$ \\
\hline Conivaptan & 151171 & Vasopressin antagonist & $-8.2 \pm 0.0$ \\
\hline Setiptiline & 5205 & Antidepressant & $-8.2 \pm 0.0$ \\
\hline Ergotamine & 8223 & Vasoconstrictor & $-8.2 \pm 0.4$ \\
\hline \multicolumn{4}{|l|}{ ZIKV MTase } \\
\hline Nilotinib & 644241 & Antineoplastic & $-10.8 \pm 0.6$ \\
\hline Tolvaptan & 443894 & Vasopressin antagonist & $-10.7 \pm 0.0$ \\
\hline Daunorubicin & 30323 & Antineoplastic & $-10.7 \pm 0.0$ \\
\hline Doxorubicin & 31703 & Antibiotic & $-10.7 \pm 0.0$ \\
\hline Viomycin & 3037981 & Antibiotic & $-10.5 \pm 0.2$ \\
\hline \multicolumn{4}{|l|}{ ZIKV NS1 } \\
\hline Nilotinib & 644241 & Antineoplastic & $-9.7 \pm 0.4$ \\
\hline Eltrombopag & 66583167 & Antithrombocytopenic & $-9.6 \pm 0.2$ \\
\hline Telmisartan & 65999 & Antihypertensive & $-9.4 \pm 0.4$ \\
\hline Adapalene & 60164 & Dermatologic & $-9.3 \pm 0.6$ \\
\hline Dihydroergotamine & 10531 & $\begin{array}{l}\text { Analgesic/ } \\
\text { vasoconstrictor }\end{array}$ & $-9.0 \pm 0.1$ \\
\hline \multicolumn{4}{|l|}{ ZIKV NS2B/NS3 } \\
\hline Teniposide & 452548 & Antineoplastic & $-9.8 \pm 0.1$ \\
\hline Eltrombopag & 66583167 & Antithrombocytopenic & $-9.4 \pm 0.3$ \\
\hline
\end{tabular}

Table 2 (continued)

\begin{tabular}{|c|c|c|c|}
\hline Name & CID & Description & $\begin{array}{l}\text { Docking affinity } \\
\text { (kcal/mol) }\end{array}$ \\
\hline Nilotinib & 644241 & Antineoplastic & $-9.4 \pm 0.3$ \\
\hline Etoposide & 36462 & Antineoplastic & $-9.2 \pm 0.1$ \\
\hline Ergotamine & 8223 & Vasoconstrictor & $-9.1 \pm 0.3$ \\
\hline Dihydroergotamine & 10531 & $\begin{array}{l}\text { Analgesic/ } \\
\text { vasoconstrictor }\end{array}$ & $-9.1 \pm 0.2$ \\
\hline \multicolumn{4}{|l|}{ ZIKV NS3 } \\
\hline Dihydroergotamine & 10531 & $\begin{array}{l}\text { Analgesic/ } \\
\text { vasoconstrictor }\end{array}$ & $-10.2 \pm 0.4$ \\
\hline Zafirlukast & 5717 & Antiasthmatic & $-9.8 \pm 0.3$ \\
\hline Conivaptan & 151171 & Vasopressin antagonist & $-9.8 \pm 0.0$ \\
\hline Nilotinib & 644241 & Antineoplastic & $-9.6 \pm 0.2$ \\
\hline Ergotamine & 8223 & Vasoconstrictor & $-9.6 \pm 0.2$ \\
\hline \multicolumn{4}{|l|}{ ZIKV NS5 } \\
\hline Ergotamine & 8223 & Vasoconstrictor & $-10.4 \pm 0.0$ \\
\hline Dihydroergotamine & 10531 & $\begin{array}{l}\text { Analgesic/ } \\
\text { vasoconstrictor }\end{array}$ & $-10.4 \pm 0.0$ \\
\hline Dutasteride & 6918296 & $5 \alpha$-reductase inhibitor & $-10.0 \pm 0.4$ \\
\hline Nilotinib & 644241 & Antineoplastic & $-10.0 \pm 0.1$ \\
\hline Ergoloid mesylate & 87068835 & Vasodilator & $-9.9 \pm 0.1$ \\
\hline Conivaptan & 151171 & Vasopressin antagonist & $-9.9 \pm 0.1$ \\
\hline \multicolumn{4}{|l|}{ CHIKV E1 } \\
\hline Natamycin & 5284447 & Antifungal & $-10.7 \pm 0.0$ \\
\hline Tubocurarine & 6000 & Neuromuscular blocker & $-10.6 \pm 0.0$ \\
\hline Eplerenone & 443872 & Diuretic & $-10.6 \pm 0.0$ \\
\hline Nilotinib & 644241 & Antineoplastic & $-10.6 \pm 0.1$ \\
\hline Ergotamine & 8223 & Vasoconstrictor & $-10.5 \pm 0.0$ \\
\hline Dihydroergotamine & 10531 & $\begin{array}{l}\text { Analgesic/ } \\
\text { vasoconstrictor }\end{array}$ & $-10.5 \pm 0.0$ \\
\hline \multicolumn{4}{|l|}{ CHIKV E2 } \\
\hline Nilotinib & 644241 & Antineoplastic & $-10.9 \pm 0.1$ \\
\hline Conivaptan & 151171 & Vasopressin antagonist & $-10.8 \pm 0.2$ \\
\hline Tubocurarine & 6000 & Neuromuscular blocker & $-10.6 \pm 0.5$ \\
\hline Ergotamine & 8223 & Vasoconstrictor & $-10.6 \pm 0.0$ \\
\hline Etoposide & 36462 & Antineoplastic & $-10.6 \pm 0.0$ \\
\hline Eltrombopag & 66583167 & Antithrombocytopenic & $-10.6 \pm 0.1$ \\
\hline Tigecycline & 54686904 & Antibiotic & $-10.6 \pm 0.1$ \\
\hline \multicolumn{4}{|l|}{ CHIKV nsP2 } \\
\hline Irinotecan & 60838 & Antineoplastic & $-9.6 \pm 0.1$ \\
\hline Nilotinib & 644241 & Antineoplastic & $-9.6 \pm 0.1$ \\
\hline Conivaptan & 151171 & Vasopressin antagonist & $-9.5 \pm 0.1$ \\
\hline Dihydroergotamine & 10531 & Antimigraine & $-9.4 \pm 0.0$ \\
\hline Zafirlukast & 5717 & Antiasthmatic & $-9.3 \pm 0.2$ \\
\hline Telmisartan & 65999 & Antihypertensive & $-9.3 \pm 0.1$ \\
\hline
\end{tabular}

and ZIKV infection (Kraus et al., 2007; Montoya et al., 2018). All drugs were tested under conditions and concentrations that did not affect cell viability (Suppl. Fig. 1). A detailed description is provided in Suppl. Methods.

\subsection{Fluorescence microscopy}

The antiviral effect of pranlukast was additionally examined using the human hepatocyte cell line (Huh-7), widely described to be highly susceptible to DENV and ZIKV infection in vitro (Chan et al., 2016; SotoAcosta et al., 2013). Additional characterization of the imaging method and infected cell count is given in Suppl. Methods.

\subsection{Intrinsic fluorescence assay}

To evaluate the potential interactions between pranlukast and nilotinib with some of the viral proteins identified after in silico analyses, we measured the intrinsic fluorescence intensity values (Byrd et al., 2013) of three recombinant proteins of DENV: envelope (recE), capsid (C), and the non-structural protein-1 (NS1). All three recombinant proteins used in this study: NS1 (The Native Antigen Company, Oxford), C (Sino Biological, Cat\# 40262-V07E) and recE (in-house produced) were certified to be $>95 \%$ pure by manufacturers and in-house 
A.

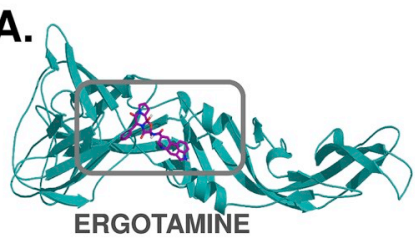

B.

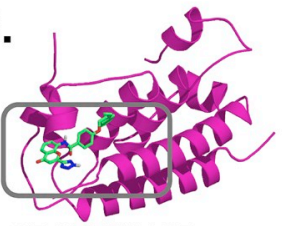

PRANLUKAST

C.

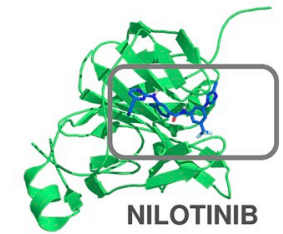

D.

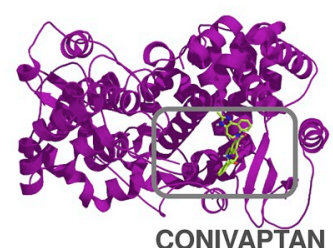

E.

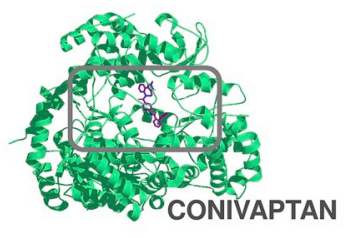

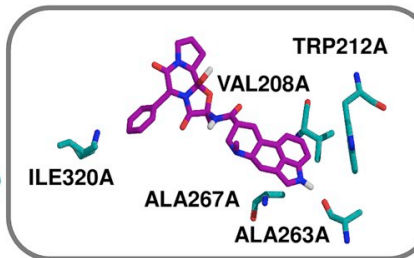
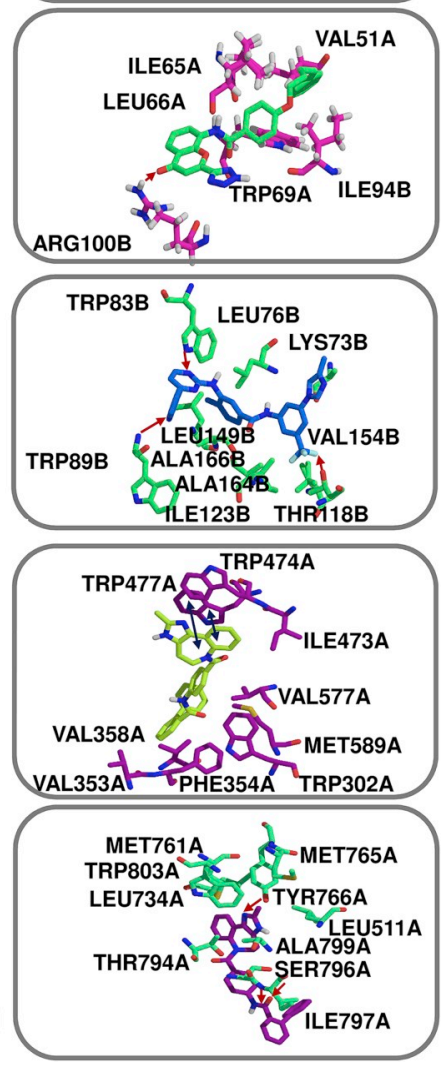

Fig. 1. Three-dimensional view of the overall structures (left) and predicted binding sites (right) of the protein-ligand complexes. A. DENV2 EErgotamine, B. DENV C-Pranlukast, C. DENV NS2B/NS3 protease-Nilotinib, D. DENV NS5-Conivaptan and E. DENV3 NS5-Conivaptan complexes. Red arrows represent hydrogen-bond acceptor features and blue arrows indicate aromatic ring interactions.

approaches as previously described (Beatty et al., 2015; Puerta-Guardo et al., 2019a) In addition, the presence and specificity of the recombinant protein was demonstrated by Western blot using specific $\alpha$ NS1 (pan-flavivirus 2B7 mAb), $\alpha$-capsid, $\alpha$-envelope (pan-flavivirus 4G2 mAb) (Suppl. Fig. 2). Further information is presented in Suppl. Methods.

\subsection{Statistical analyses}

All statistical analyses and graphs were performed and generated using GraphPad Prism 6 software. Multiple comparison analyses between three or more groups were conducted using an ordinary two-way analysis of variance (ANOVA). Comparison between two groups were carried out using $\mathrm{t}$ tests (non-parametric) (Mann-Whitney test). Differences were considered significant for $\mathrm{p}$ values $<0.05$.

\section{Results}

\subsection{Viral proteins and ligand structures}

Fifteen DENV, ZIKV and CHIKV proteins (Table 1) were found to have an available crystal structure with suitable resolution and were
A.

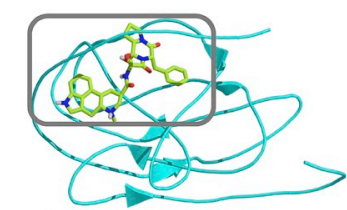

ERGOTAMINE

B.

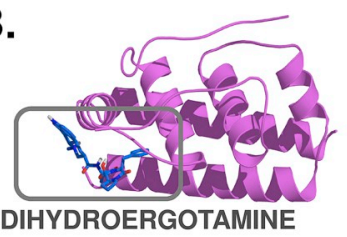

C.

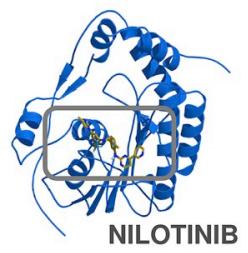

D.

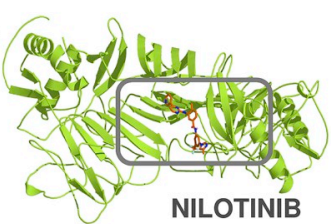

E.

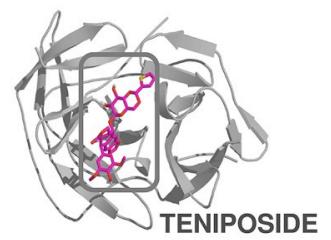

F.

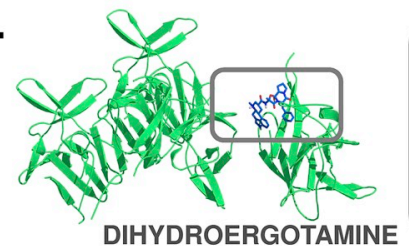

G.

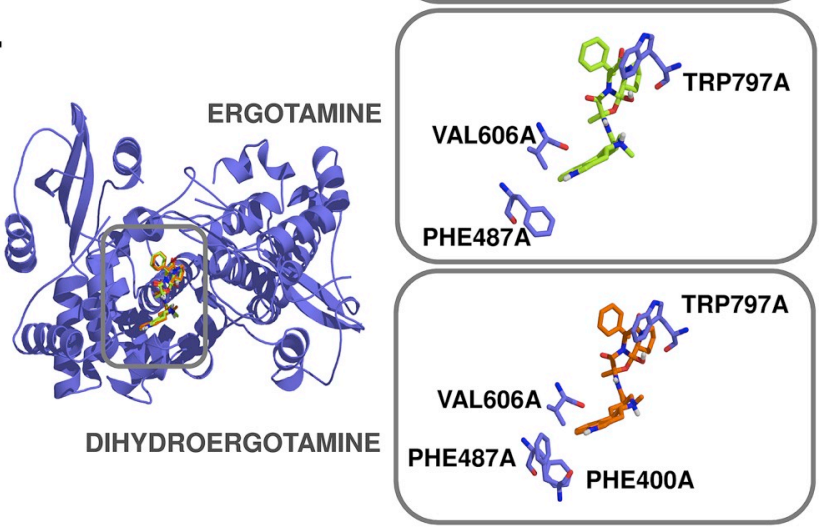

Fig. 2. Three-dimensional view of the overall structures (left) and predicted binding sites (right) of the protein-ligand complexes. A. ZIKV EErgotamine, B. ZIKV C-Dihydroergotamine, C. ZIKV NS5 MTase-Nilotinib, D. ZIKV NS1-Nilotinib, E. ZIKV NS2B/NS3-Teniposide, F. ZIKV NS3Dihydroergotamine, G. ZIKV NS5-Dihydroergotamine (orange) and ZIKV NS5Ergotamine (green). Red arrows represent hydrogen-bond acceptor features, blue arrows indicate aromatic ring interactions and green arrows represent hydrogen-bond acceptor and donor features. 


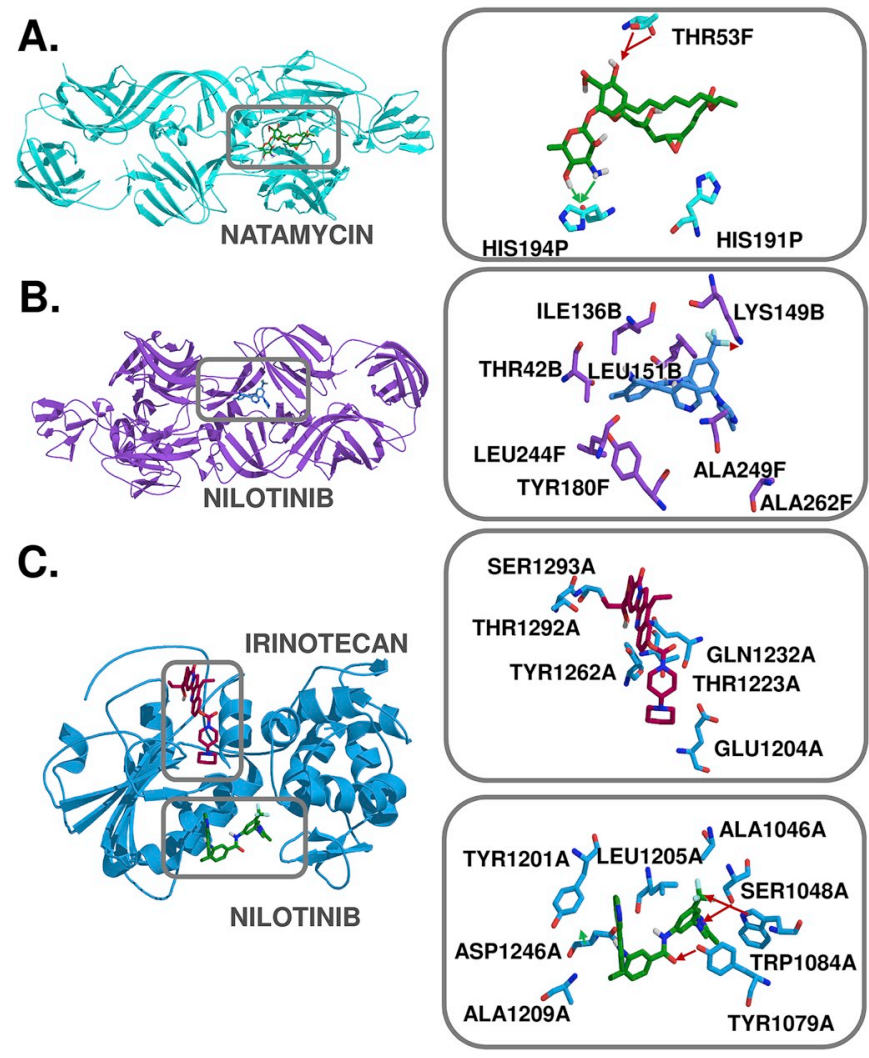

Fig. 3. Three-dimensional view of the overall structures (left) and predicted binding sites (right) of the protein-ligand complexes. A. CHIKV E1Natamycin, B. CHIKV E2-Nilotinib, C. CHIKV nsP2-Irinotecan (magenta) and CHIKV nsP2-Nilotinib (green) complexes. Red and green arrows represent hydrogen-bond acceptor and donor features, respectively.

downloaded from PDB (http://www.rcsb.org/) (Bernstein et al., 1977). A total of 1,597 pharmaceutical compounds (Suppl. Table 2-4) were obtained from DrugBank (Law et al., 2014) and prepared according to our protocol (Cabarcas-Montalvo et al., 2016; Montes-Grajales et al., 2016, 2013; Montes-Grajales and Olivero-Verbel, 2013).

\subsection{Small molecule drugs have differential affinity to viral proteins of DENV, ZIKV and CHIKV}

AutoDock Vina affinity scores for small-molecule drugs with DENV, ZIKV and CHIKV proteins are presented in Suppl. Tables 2-4, respectively; and a summary with the best docking results per protein target are shown in Table 2. These ranged from -11.4 to $-1.0 \mathrm{kcal} / \mathrm{mol}$. Interestingly, several different types of drugs, including vasoconstrictors, analgesics, antineoplasics, anti-inflammatories, antibiotics and antihistamines, among others, presented high affinity scores $(\leq-9.0 \mathrm{kcal} / \mathrm{mol})$ for the viral proteins tested. To better visualize these results, a clustered heatmap based on docking affinity scores of DENV, ZIKV and CHIKV proteins against pharmaceuticals is shown in Suppl. Fig. 3.

Regarding DENV, the proteins DENV2 E, DENV C and DENV NS2B/ NS3 exhibited their highest docking affinity scores with the vasoconstrictor ergotamine $(-9.8 \mathrm{kcal} / \mathrm{mol})$, the antiasmathic pranlukast $(-9.1 \mathrm{kcal} / \mathrm{mol})$ and the antineoplastic agent nilotinib $(-10.6 \mathrm{kcal} /$ mol), respectively. In addition, two DENV proteins displayed the highest affinity with the vasopressin antagonist conivaptan, with affinity scores of $-10.6 \mathrm{kcal} / \mathrm{mol}$ for DENV NS5 and $-11.4 \mathrm{kcal} / \mathrm{mol}$ for DENV3 NS5. Three proteins studied from CHIKV demonstrated highest binding affinity value: E1 with the antifungal natamycin $(-10.7 \mathrm{kcal} /$ $\mathrm{mol})$, and E2 and nsP2 with nilotinib $(-10.9 \mathrm{kcal} / \mathrm{mol}$ and $-9.6 \mathrm{kcal} /$ mol, respectively). ZIKV proteins NS1 and NS5 MTase obtained the best affinity score with nilotinib ( -9.7 and $-10.8 \mathrm{kcal} / \mathrm{mol}$, respectively); NS5, C, and NS3 with dihydroergotamine $(-10.4,-8.9$ and $-10.2 \mathrm{kcal} / \mathrm{mol}$, respectively); E and NS5 with ergotamine ( $-9.3 \mathrm{kcal} /$ $\mathrm{mol}$ and $-10.4 \mathrm{kcal} / \mathrm{mol}$, respectively), and the NS2/NS3 complex with teniposide $(-9.8 \mathrm{kcal} / \mathrm{mol})$.

\subsection{Small molecules drugs interact with distinct viral proteins via hydrophobic interactions}

Results obtained from LigandScout (Wolber and Langer, 2005) showed that most of the protein-ligand interactions between DENV, ZIKV and CHIKV proteins with the candidate pharmaceuticals are hydrophobic, with the presence of some aromatic interactions and hydrogen bonds. The contact residues and type of interactions of the complexes with the best affinity scores are presented in Figs. 1-3, and those for pranlukast are available in Suppl. Fig. 4.

\subsection{Pranlukast reduces DENV and ZIKV infection of human monocytic cells and human hepatocytes in vitro, potentially blocking virus entry}

Here, human monocytic cells (U937-DC-SIGN) were infected using a pre-mixed preparation of purified DENV or ZIKV with several concentrations of pranlukast, nilotinib, conivaptan, itraconazole and novobiocin (Suppl. Table 1; Fig. 4). Twenty-four hours post-infection, pranlukast was the only tested compound that significantly inhibited the infection of U937-DC-SIGN cells, as measured by flow cytometry using NS3 as a marker for viral replication (Fig. 4A). Compared to DMSO-treated cells that were infected with DENV (21\%) or ZIKV (17\%), pranlukast showed an important reduction in expression of NS3 in cells infected with either DENV ( $\mathrm{IC}_{50}=11.85 \mu \mathrm{M}$ ) or ZIKV $\left(\mathrm{IC}_{50}=22.28 \mu \mathrm{M}\right)(\mathrm{Fig} .4 \mathrm{~A})$. Other compounds such as conivaptan and novobiocin (Fig. 4C, E) showed promising inhibitory effects for both DENV and ZIKV infections (Fig. 4C, E). In contrast, nilotinib and itraconazole showed no antiviral activity against either DENV or ZIKV infection of human monocytic cells (Fig. 4B, D). With these results, we additionally characterized the antiviral activity of pranlukast in DENV and ZIKV infection in vitro by determining the percentage of infected human monocytic cells and also the amount of virus production using the standard Vero focus forming assay (FFU/mL). Pranlukast reduced both the amount of DENV and ZIKV-infected cells after $24 \mathrm{~h}$ posttreatment and also reduced the infectivity of virus production from treated cells (Fig. 5A-C). A similar inhibitory effect was achieved by different concentrations of pranlukast (range: 50-12.5 $\mu \mathrm{M}$ ) in human monocytic cells infected with DENV and ZIKV using different MOIs $(0.1,0.5,1)$ (Fig. 5D) or human hepatocytes in which pranlukast $(50-12.5 \mu \mathrm{M})$ but not nilotinib $(25-12.5 \mu \mathrm{M})$ inhibited DENV and ZIKV infection after $24 \mathrm{~h}$ post-treatment (Fig. 6A-C). The differences in the concentrations tested for both compounds resulted from the analysis of the cell viability test (Suppl. Fig. 1), which revealed that nilotinib reduced the viability of human monocytic cells ( $>20 \%$ cytotoxicity) at concentrations between 100 and $50 \mu \mathrm{M}$, while, pranlukast only affected cell viability at $100 \mu \mathrm{M}$. Further, pranlukast appeared to affect the early stages of DENV and ZIKV infection, as the percentage of infected cells was markedly reduced when virus and pranlukast were simultaneously added to infect U937 cells (Fig. 7A), compared to an alternative protocol when pranlukast was added $2 \mathrm{~h}$ after infection was initiated (Fig. 7B). Additionally, pranlukast $(50-12.5 \mu \mathrm{M})$ but not nilotinib blocked more than $90 \%$ of DENV attachment to the surface of human monocytic cells (Fig. 7C). Attached virus was removed after treatment with glycine acid, a buffer that dissociate cell-surface associated virus on cell membranes (Fig. 7C). Together, these data show that pranlukast inhibited the infection of human monocytic cells with DENV or ZIKV under the conditions tested and affected DENV absorption on cell membranes. 
A

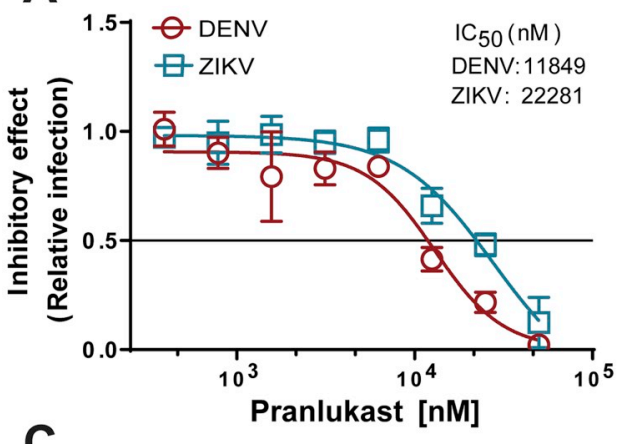

C

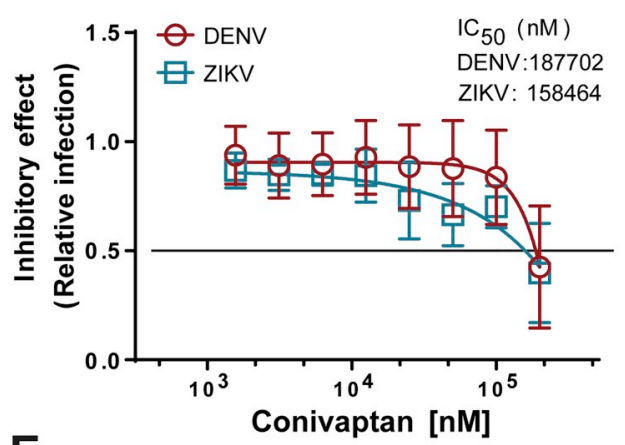

E

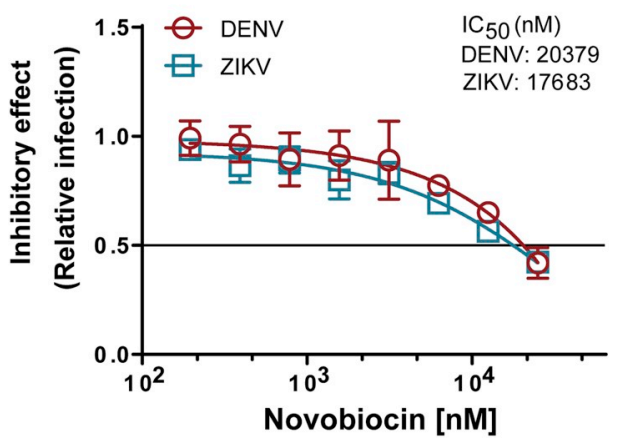

B

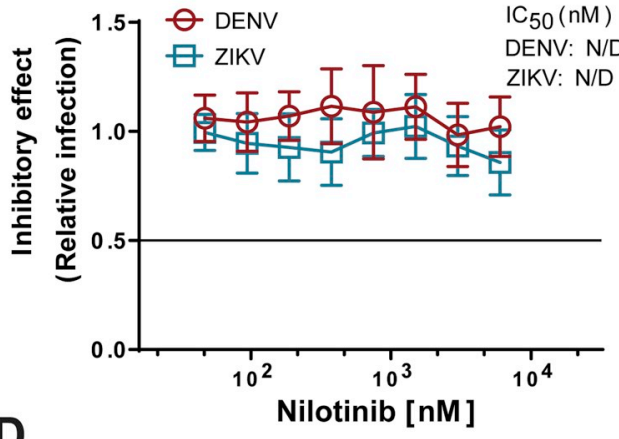

D

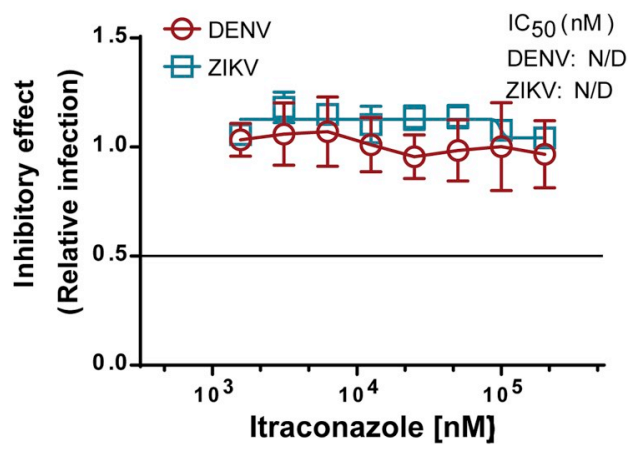

Fig. 4. Antiviral activity of in silico repurposed drug compounds against DENV and ZIKV infection of human monocytic cells in vitro. Human monocytic cells infected with DENV or ZIKV in the presence and absence of several concentrations (nM) of pranlukast, nilotinib, conivaptan, itraconazole and novobiocin (Table 1). Infection was determined after $24 \mathrm{~h}$ post-infection by detecting the viral replication marker NS3 using flow cytometry. Graphs represent the inhibitory effect for each compound against DENV and ZIKV infection of human monocytic cells. The inhibitory effect was expressed as the relative infection of non-infected cells (background) vs cells infected in the presence or absence of eight-different concentrations of each compound (nM). Analyses by nonlinear regression (curve fit) with variable slope predicted the $\mathrm{IC}_{50}$ as the measure of the antiviral effect potency of each compound against DENV or ZIKV infection of human monocytic cells. Each point represents the mean neutralization value from the two replicates, and the error bars depict the standard deviations. Neutralization experiments were repeated several times for pranlukast $(n=7)$, nilotinib ( $\mathrm{n}=13)$, conivaptan $(\mathrm{n}=9)$, itraconazole $(n=4)$, and novobiocin $(n=4)$.

\subsection{Pranlukast interacts with DENV proteins in vitro}

Here, the intrinsic fluorescence values of three viral proteins E, C, and NS1 $(200 \mathrm{ng} / \mathrm{mL})$ were measured in the presence and absence of pranlukast $(50 \mu \mathrm{M})$ and nilotinib $(25 \mu \mathrm{M})$ (Fig. 8). All three recombinant proteins diluted in PBS( $1 \mathrm{x})$ and DMSO $(0.5 \%)$ showed similar fluorescence values at the wavelengths included in the assay (300, 320, 340, $360 \mathrm{~nm}$ ) (Fig. 8A-F). Interestingly, pranlukast significantly decreased the intrinsic fluorescence intensities of all three proteins, especially at the wavelength of $300 \mathrm{~nm}$, where all three proteins showed a peak of maximum fluorescence, which were not saturating for the detection system (NS1: 25\%; E: 30\%; C: 20\%; Fig. 8). Neither DMSO nor nilotinib affected the intrinsic protein fluorescence of any of these three proteins $(<1 \%)$ (Fig. 8A-F). Fluorescence values obtained with pranlukast and nilotinib alone are presented in Figure Suppl. Fig. 5. Together these results suggest that pranlukast interacts with these three viral proteins in vitro.

\section{Discussion}

Several already-approved drugs exhibited high in silico binding affinity for DENV, ZIKV and CHIKV proteins; including vasoconstrictors, analgesics, antineoplasics, anti-inflammatories, antibiotics and antihistamines. Interactions were predominantly hydrophobic with some hydrogen bonds, aromatic ring interactions and negative ionizable areas, which may contribute to stabilize the ligands at the target site and confer high affinity (Makhatadze and Privalov, 1995; Patil et al., 2010; Young et al., 2007).

Envelope proteins of DENV, ZIKV and CHIKV, involved in virus binding and membrane fusion, were found to have the best in silico affinity to many of the pharmaceutical compounds. Similar results were found for several non-structural proteins including NS2B, NS3, and NS5 from DENV and ZIKV; as well as for ZIKV NS1 and CHIKV nsP2.

Among the compounds tested in vitro, only the anti-asthmatic drug pranlukast exhibited a significant inhibition in the infection of human monocytic cells and human hepatocytes with DENV and ZIKV using in vitro cell culture models, potentially interfering with virus binding and/ or entry into target cells via direct interaction with some viral proteins such as NS1, envelope and capsid. As a leukotriene receptor antagonist, pranlukast has been widely used to prevent seasonal virus-induced asthma exacerbation (Keam et al., 2003; Kim et al., 2016). However, the potential antiviral activity of pranlukast had not been addressed. These findings suggest that approved drugs available on the market may have potential therapeutic application against replication/transmission of arboviruses.

The in silico screening showed that pranlukast may interact with several viral targets (Suppl. Fig. 4). The interactions among those complexes appear to be characterized by hydrophobic interactions with 
A
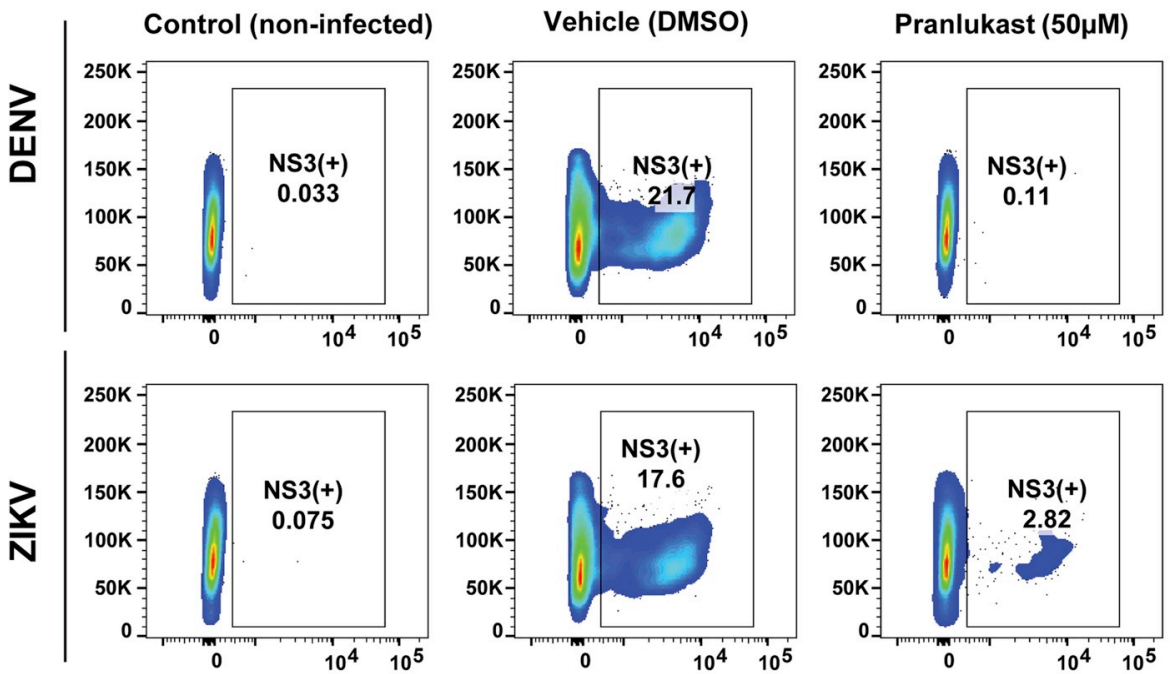

B

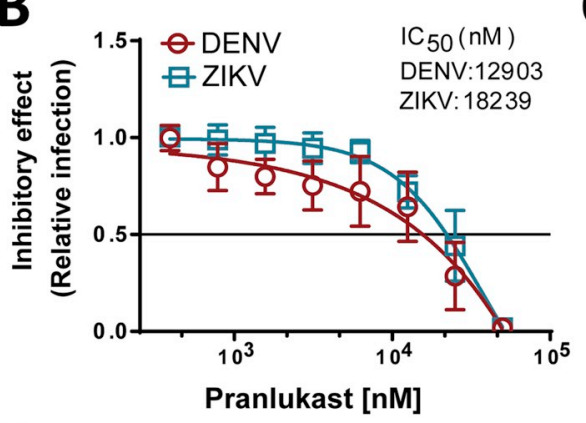

D
C

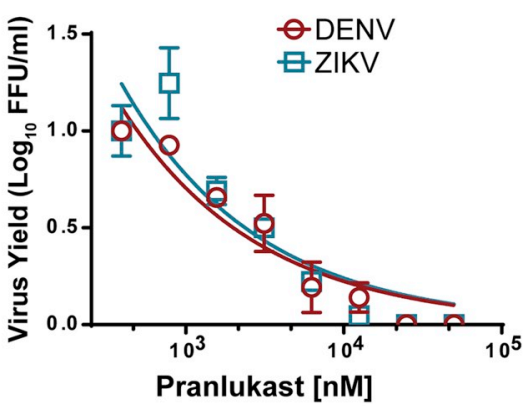

Fig. 5. Pranlukast reduces DENV and ZIKV infection of human monocytic cells and production of virus infectious particles. A. Representative cell counter plots for DENV and ZIKV infection of untreated, DMSO-treated and pranlukast-treated (50 $\mu \mathrm{M})$ U937 DC-SIGN-expressing cells measured by flow cytometry using NS3 expression (gate NS3 +) as an active flavivirus replication marker. B. Inhibitory effect of pranlukast $(50-0.390 \mu \mathrm{M})$ on DENV and ZIKV infection of U937-DC-SIGN cells at $24 \mathrm{~h}$ posttreatment. Non-infected cells and cells infected in the presence of DMSO (vehicle) were used as baseline for relative infection. Data represent mean \pm standard error of the mean (SEM) of five individual experiments run in duplicate. C. Vero focus forming assay to detect virus infectious particles in supernatants collected from U937-DC-SING infected with DENV and ZIKV in the presence and absence of pranlukast $(50-0.390 \mu \mathrm{M})$. Data represent mean \pm SEM of two different experiments run in duplicate. D. Effect of pranlukast and nilotinib on DENV and ZIKV infection of human monocytic cells at different MOIs. U937DC-SIGN cells were infected with a pre-mixed of DENV or ZIKV (MOIs: 0.1., 0.5., 1) plus pranlukast $(50,25,12.5 \mu \mathrm{M})$. Infection was evaluated after $24 \mathrm{~h}$ post-treatment using flow cytometry assay. No differences were detected between non-infected and Mock-infected cells as well as non-treated cells and DMSO-treated (drug vehicle control) cells infected with either DENV or ZIKV. Data represent mean \pm SEM of five different experiments run in duplicate.

\section{$\begin{array}{lllll}\text { Pranlukast }[\mu \mathrm{M}] & \square 0 & \square & \square & \square\end{array}$}

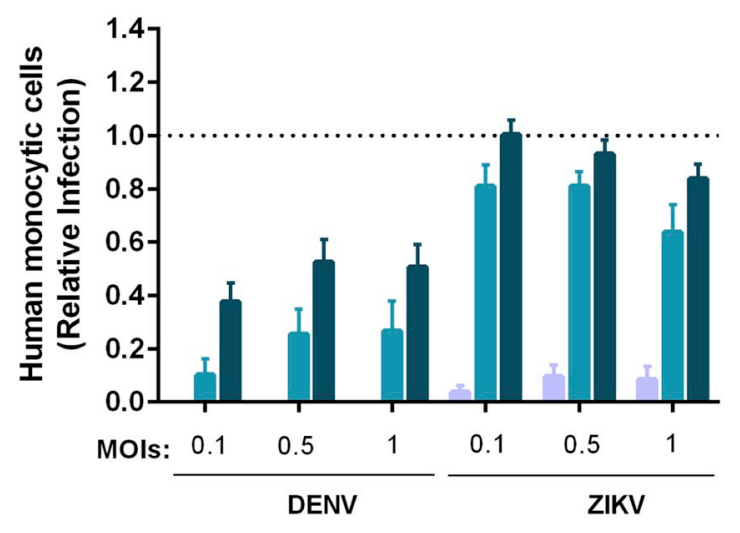

some hydrogen bonds and aromatic-aromatic ring interactions. Pranlukast exhibited three polar interactions with CHIKV E1 and CHIKV E2 (ARG247F, TYR180F and LYS181F), in the same binding pocket reported for other promising molecules able to inhibit CHIKV replication (Mishra et al., 2016), and two polar interactions with DENV2 E (SER29A and SER363A) and ZIKV E (LYS100A and PHE18A). Analyses by intrinsic fluorescence assay, showed an apparent interaction between pranlukast and three viral proteins such as E, NS1 and C, suggesting a potential antiviral mechanism of pranlukast against DENV and ZIKV.

Here, our in vitro data showed that pranlukast possesses inhibitory activity against DENV and ZIKV infection of human monocytic cells and also human hepatocytes cells, two main cellular targets described for
DENV and ZIKV (Chan et al., 2016; Soto-Acosta et al., 2013). Additional results suggested that pranlukast inhibited DENV and ZIKV infection of human monocytic cells at different MOIs. This inhibitory effect was mediated by blocking virus attachment, which may abrogate virus entry. Interestingly, pranlukast interacts with DENV proteins that play critical roles not only in virus entry but also virus replication such as envelope (E) and capsid (C). Protein E and C, two major structural proteins of flavivirus, play important roles in host cell viral interactions and virus morphogenesis (Samsa et al., 2009; Zhang et al., 2017). Our data suggests that pranlukast binding to E protein, may diminish virus attachment to the cell surface leading to reduced DENV and ZIKV infection in human cells. Surprisingly, pranlukast binds to NS1, a secreted viral protein important for immune evasion and pathogenesis (Beatty 


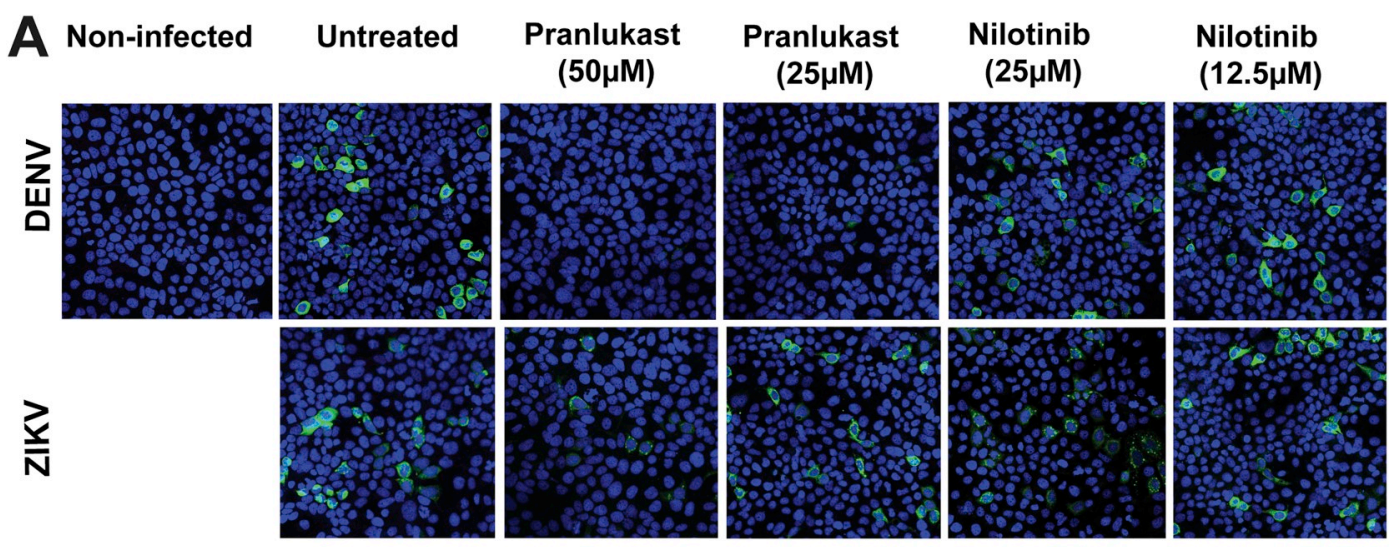

B

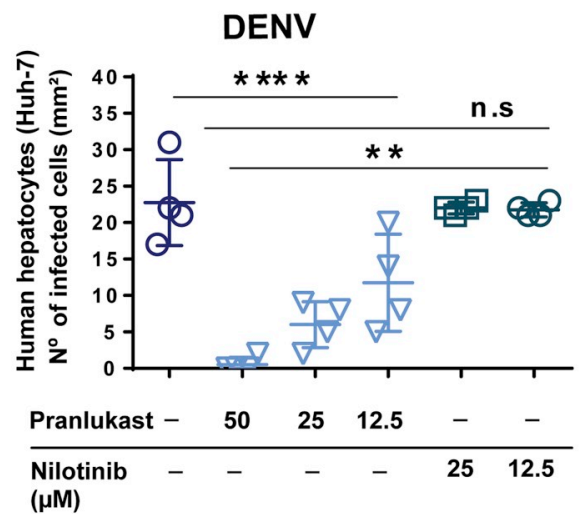

C

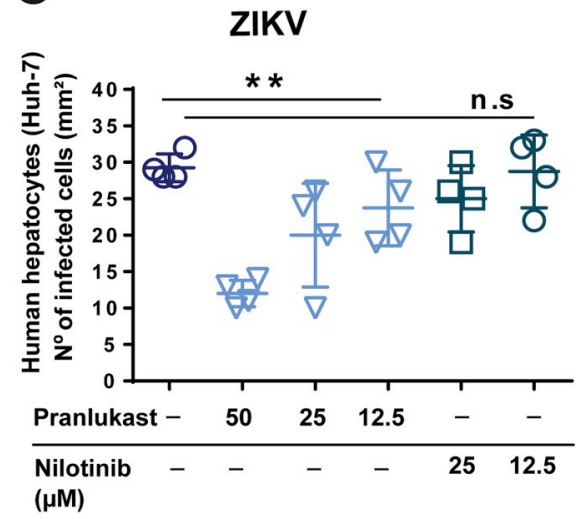

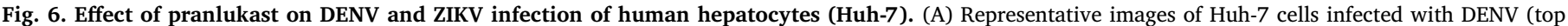

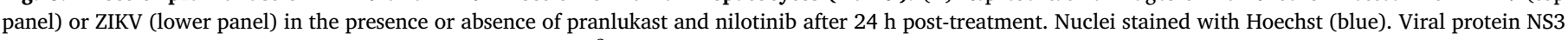
(green). B, C. Number of infected cells per standard area $\left(\mu \mathrm{M}^{2}\right)$ counted using ImageJ software analyses. ( $\left.=4\right)$.

A

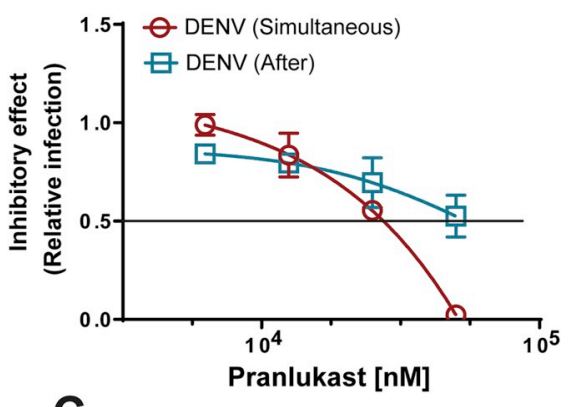

C

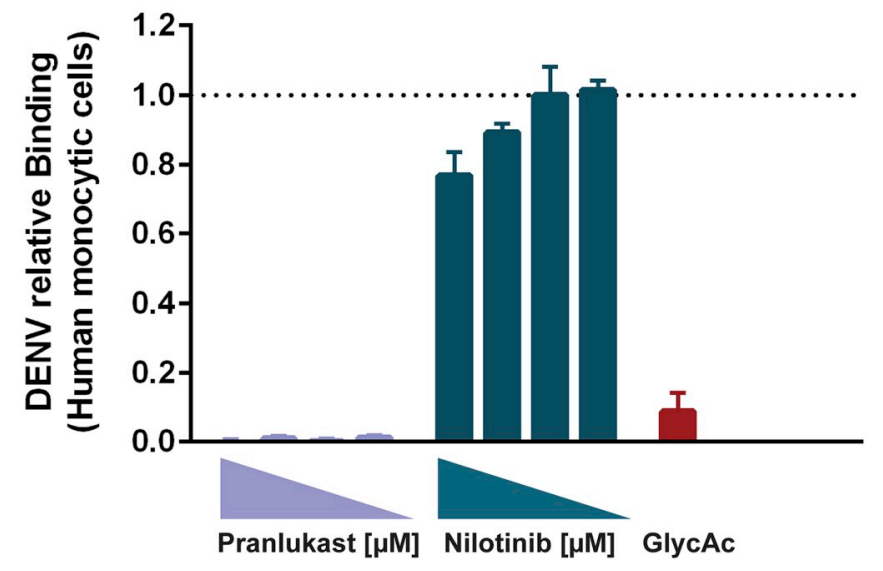

Fig. 7. Pranlukast reduces virus entry by blocking virus attachment to the surface of human monocytic cells. A-B. Pranlukast (50-6.25 $\mu \mathrm{M})$ was added either simultaneously (pre-mixed virus plus drug) or after $2 \mathrm{~h}$ post-infection. DENV and ZIKV infection was examined after 24 h-post-treatment by flow cytometry analyses detecting the viral protein NS3. C. DENV attachment to cell surface was examined in the presence and absence of pranlukast $(50-6.25 \mu \mathrm{M})$ and nilotinib $(25-3.125 \mu \mathrm{M})$ with glycine acid (GlycAc) which removed any surfacebound, non-internalized virion from the outer cell membrane used as control.The amount of surface-bound virus was measured by flow cytometry using direct virus staining with an anti-envelope mAb (4G2-Alexa 568). DENV relative binding for all experimental conditions was estimated using the fluorescence signal obtained from human monocytic cells exposed to virus alone treated with DMSO and no virus treated cells used as background controls. 

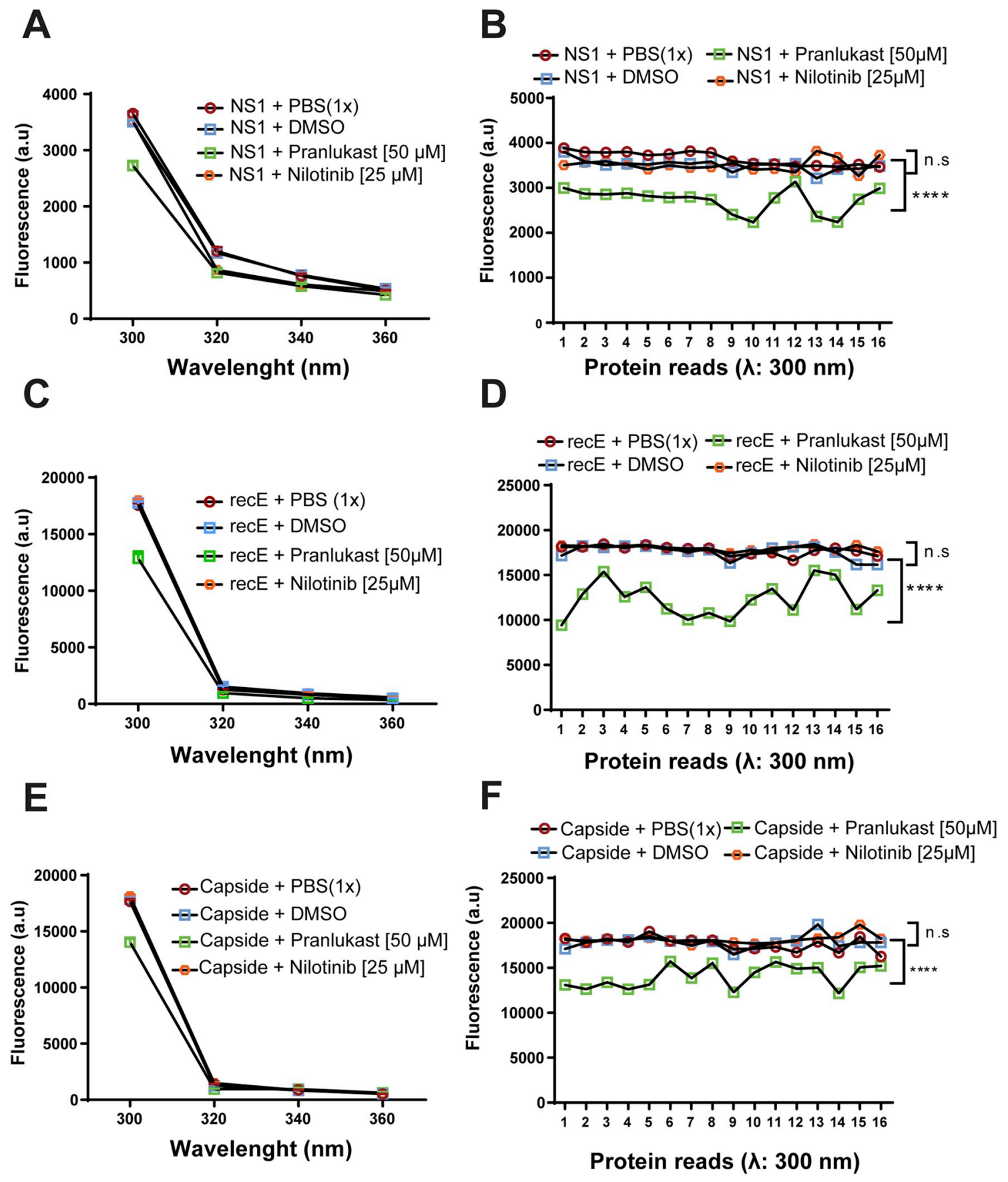

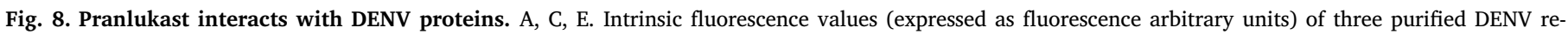

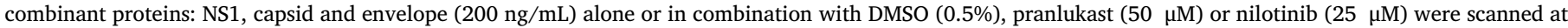

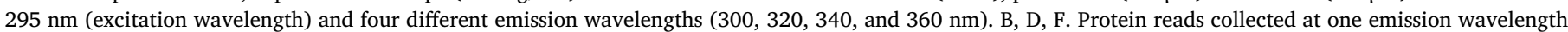

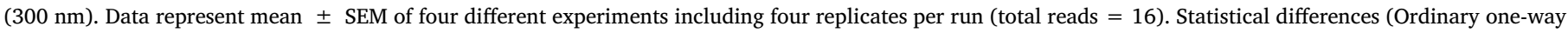
ANOVA; Mann-Whitney non-parametric test) were considered significant as p values $<0.5$.

et al., 2015; Glasner et al., 2018; Puerta-Guardo et al., 2019b). Further analyses using different molecular tools to evaluate its effect on virus internalization as well as viral RNA replication and also potential blocking effect on NS1 mediated-endothelial hyperpermeability would help to elucidate which steps of the viral replication cycle and viral pathogenesis are affected by pranlukast. Additionally, future studies to examine the antiviral effect of these compounds on the infection of other arboviruses such as chikungunya (CHIKV) should be addressed. Importantly, these results support our findings from the virtual screening that identified that pranlukast has a high affinity for the envelope proteins of DENV, ZIKV, and CHIKV.
A considerable number of antineoplastic agents, commonly used for cancer treatment, such as nilotinib (Schneider et al., 2015), displayed in silico interaction with DENV, ZIKV and CHIKV proteins ( $\leq-9.0 \mathrm{kcal} /$ mol). The use of this kind of molecules as antivirals is not recommended due to their significant side effects (Afzal et al., 2015; Henß et al., 2016; Stein et al., 1989). In this study, nilotinib showed no antiviral activity on DENV or ZIKV infection of human monocytes or hepatocytes in vitro neither bind to any of the viral proteins tested, however, it appeared to inhibit some virus attachment to the cell surface. Nilotinib has shown antiviral activity against cytomegalovirus infection and other related molecules such as sunitinib or erlotinib had inhibited dengue virus 
which suggest that kinase inhibitors still represent interesting drugs with potential antiviral activity (Bekerman et al., 2017; Pu et al., 2018; Wolf et al., 2012).

In addition, other widely used drugs, such as the analgesic antrafenine (de Gara et al., 1982), the antifungals itraconazole, natamycin and ketoconazole (Carrilo-Muñoz et al., 1996; Zuckerman and Tunkel, 1994), the antibiotics novobiocin, cefoperazone, rolitetracycline, cefpiramide, piperacillin, dalfopristin and viomycin (Chant and Rybak, 1995; Finlay et al., 1951; Freel Meyers et al., 2003; Iakovlev and Kaplar-Vuchevats, 1994; Mazzola et al., 1980; Nolting et al., 1996; Pfaller et al., 2017), the antifungal natamycin (Balaguer et al., 2014), the antimycobacterial clofazimine (Cholo et al., 2017), the vasoconstrictor ergotamine (Tfelt-Hansen and Koehler, 2008), and the vasopressin antagonist conivaptan (Annane et al., 2009), among others, showed good affinity values with tested viral proteins. These proteins have shown to be critical for viral-cell membrane fusion (Allison et al., 2001; Chen et al., 1996; Crill and Roehrig, 2001; Garoff et al., 2004; Kielian et al., 2010; Modis et al., 2004; Voss et al., 2010; Weber et al., 2017), virus entry and recruiting of the viral genome during viral encapsulation and nucleocapsid creation (Ma et al., 2004; E. R. A. Oliveira et al., 2017; Rodenhuis-Zybert et al., 2010; Marcelo M Samsa et al., 2009), viral genome replication (Erbel et al., 2006; Lim et al., 2016; A. F. C. da S. Oliveira et al., 2017; Patil et al., 2010; Yap et al., 2007), and neutralization of cellular antiviral responses (Ahola and Merits, 2016; Akhrymuk et al., 2012; Fros et al., 2015, 2010). The analgesic antrafenine is also one of the most promising candidates due to its strong interaction with DENV2 E, DENV NS2B/NS3 and DENV3 NS5 proteins, along with all CHIKV and ZIKV studied proteins. Here, itraconazole did not inhibit the infection of DENV and ZIKV in human monocytic cells. Interestingly, conivaptan and novobiocin showed some antiviral activity against DENV and ZIKV at high concentrations. Novobiocin, a natural antibiotic that inhibits DNA gyrase, has been shown to poses some antiviral activity inhibiting vaccinia and herpesvirus (GonzálezMolleda et al., 2012; Sekiguchi and Shuman, 1997). This finding points out these two compounds as potential candidates for future development of new antiviral molecules based on their chemical structures. Therefore, these drugs being less aggressive than anticancer agents could be considered for future in vivo tests aimed at evaluating their inhibitory activity against DENV, ZIKV, and CHIKV. This finding constitutes an initial approach for future studies to demonstrate the potential effect of these existing licensed drugs against human arboviral infections in vitro and in vivo.

In conclusion, these findings suggest that approved drugs available on the market may have potential therapeutic application against replication/transmission of arboviruses. Further, pranlukast showed promising antiviral activity against DENV and ZIKV primarily affecting the viral entry step when tested on human monocytic cells and human hepatocytes used as in vitro models for viral infection. Additionally, the antiviral activity of pranlukast against DENV and ZIKV may be rely on direct interaction with viral proteins critical for virus replication such as E, NS1, and C. Further analyses using more advanced tools (e.g. ultrafiltration, affinity chromatograph, biolayer interferometry, surface plasmon resonance) are needed to better characterize viral protein binding as well as binding affinity to FDA-approved drugs or new drug candidates. In a current scenario where no specific therapeutics and safe vaccines for these arboviral infections are available, the repurposing of approved drugs targeting viral proteins required for infection (Xie et al., 2015; Lim et al., 2016; de Silva et al., 2018; Glasner et al., 2018; Puerta-Guardo et al., 2019; Subudhi et al., 2018) still represents a promising approach for discovering new antiviral activities in FDA-approved drugs that can help to fight back important human diseases such as those caused by arboviruses.

\section{Declaration of competing interest}

The authors declare that there is no conflict of interest.

\section{Acknowledgements}

The authors wish to thank the Administrative Department of Science, Technology and Innovation of Colombia [Grant: Colciencias No. 811-2018], Universidad Nacional Autónoma de México [Grant: Programa de Becas Posdoctorales en la UNAM 2016], Universidad Tecnológica de Bolívar [Grant: TRFCI-1P2016] and the National Institutes of Health [NIH grant R01 AI24493] for their financial support.

\section{Appendix A. Supplementary data}

Supplementary data to this article can be found online at https:// doi.org/10.1016/j.antiviral.2019.104668.

\section{References}

Abdulla, M.-H., Ruelas, D.S., Wolff, B., Snedecor, J., Lim, K.-C., Xu, F., Renslo, A.R., Williams, J., McKerrow, J.H., Caffrey, C.R., 2009. Drug discovery for schistosomiasis: hit and lead compounds identified in a library of known drugs by mediumthroughput phenotypic screening. PLoS Neglected Trop. Dis. 3, e478. https://doi. org/10.1371/journal.pntd.0000478.

Afzal, O., Kumar, S., Haider, M.R., Ali, M.R., Kumar, R., Jaggi, M., Bawa, S., 2015. A review on anticancer potential of bioactive heterocycle quinoline. Eur. J. Med. Chem. 97, 871-910. https://doi.org/10.1016/j.ejmech.2014.07.044.

Aguiar, M., Stollenwerk, N., 2018. Dengvaxia: age as surrogate for serostatus. Lancet Infect. Dis. https://doi.org/10.1016/S1473-3099(17)30752-1.

Ahola, T., Merits, A., 2016. Functions of chikungunya virus nonstructural proteins. In Okeoma, C.M. (Ed.), Chikungunya Virus: Advances in Biology, Pathogenesis, and Treatment. Springer International Publishing, Cham, pp. 75-98. https://doi.org/10. 1007/978-3-319-42958-8 6.

Akhrymuk, I., Kulemzin, S.V., Frolova, E.I., 2012. Evasion of the innate immune response: the old world alphavirus nsP2 protein induces rapid degradation of Rpb1, a catalytic subunit of RNA polymerase II. J. Virol. 86, 7180-7191. https://doi.org/10.1128/JVI. 00541-12.

Allison, S.L., Schalich, J., Stiasny, K., Mandl, C.W., Heinz, F.X., 2001. Mutational evidence for an internal fusion peptide in flavivirus envelope protein E. J. Virol. 75, 4268-4275. https://doi.org/10.1128/JVI.75.9.4268-4275.2001.

Annane, D., Decaux, G., Smith, N., 2009. Efficacy and safety of oral conivaptan, a vasopressin-receptor antagonist, evaluated in a randomized, controlled trial in patients with euvolemic or hypervolemic hyponatremia. Am. J. Med. Sci. 337, 28-36. https:// doi.org/10.1097/MAJ.0b013e31817b8148.

Balaguer, M.P., Fajardo, P., Gartner, H., Gomez-Estaca, J., Gavara, R., Almenar, E., Hernandez-Munoz, P., 2014. Functional properties and antifungal activity of films based on gliadins containing cinnamaldehyde and natamycin. Int. J. Food Microbiol. 173, 62-71. https://doi.org/10.1016/j.ijfoodmicro.2013.12.013.

Bastos, L.F.S., Coelho, M.M., 2014. Drug repositioning: playing dirty to kill pain. CNS Drugs 28, 45-61. https://doi.org/10.1007/s40263-013-0128-0.

Beatty, P.R., Puerta-Guardo, H., Killingbeck, S.S., Glasner, D.R., Hopkins, K., Harris, E., 2015. Dengue virus NS1 triggers endothelial permeability and vascular leak that is prevented by NS1 vaccination. Sci. Transl. Med. 7. https://doi.org/10.1126/ scitranslmed.aaa3787.

Bekerman, E., Einav, S., 2015. Combating emerging viral threats. Science 348, 282-283. https://doi.org/10.1126/science.aaa3778.

Bekerman, E., Neveu, G., Shulla, A., Brannan, J., Pu, S.Y., Wang, S., Xiao, F., BarouchBentov, R., Bakken, R.R., Mateo, R., Govero, J., Nagamine, C.M., Diamond, M.S., De Jonghe, S., Herdewijn, P., Dye, J.M., Randall, G., Einav, S., 2017. Anticancer kinase inhibitors impair intracellular viral trafficking and exert broad-spectrum antiviral effects. J. Clin. Investig. 127, 1338-1352. https://doi.org/10.1172/JCI89857.

Bernstein, F.C., Koetzle, T.F., Williams, G.J.B., Meyer, E.F., Brice, M.D., Rodgers, J.R., Olga, K., Shimanouchi, T., Tasumi, M., 1977. The protein Data Bank. A computer based archival file for macromolecular structures. Eur. J. Biochem. 80, 319-324. https://doi.org/10.1111/j.1432-1033.1977.tb11885.x.

Byrd, C.M., Dai, D., Grosenbach, D.W., Berhanu, A., Jones, K.F., Cardwell, K.B., Schneider, C., Wineinger, K.A., Page, J.M., Harver, C., Stavale, E., Tyavanagimatt, S., Stone, M.A., Bartenschlager, R., Scaturro, P., Hruby, D.E., Jordan, R., 2013. A novel inhibitor of dengue virus replication that targets the capsid protein. Antimicrob. Agents Chemother. 57, 15-25. https://doi.org/10.1128/AAC.01429-12.

Cabarcas-Montalvo, M., Maldonado-Rojas, W., Montes-Grajales, D., Bertel-Sevilla, A., Wagner-Döbler, I., Sztajer, H., Reck, M., Flechas-Alarcon, M., Ocazionez, R., OliveroVerbel, J., 2016. Discovery of antiviral molecules for dengue: in silico search and biological evaluation. Eur. J. Med. Chem. 110, 87-97. https://doi.org/10.1016/j. ejmech.2015.12.030.

Calvo, E.P., Coronel-Ruiz, C., Velazco, S., Velandia-Romero, M., Castellanos, J.E., 2015. Diagnóstico diferencial dengue-chikungunya en pacientes pediátricos. Biomedica 36. https://doi.org/10.7705/biomedica.v36i0.2982.

Carrilo-Muñoz, A.J., Tur, C., Torres, J., Seymour, A.C., 1996. In-vitro antifungal activity of sertaconazole, bifonazole, ketoconazole, and miconazole against yeasts of the Candida genus. J. Antimicrob. Chemother. 37, 815-819. https://doi.org/10.1093/ jac/37.4.815. 
Chan, J.F.W., Yip, C.C.Y., Tsang, J.O.L., Tee, K.M., Cai, J.P., Chik, K.K.H., Zhu, Z., Chan, C.C.S., Choi, G.K.Y., Sridhar, S., Zhang, A.J., Lu, G., Chiu, K., Lo, A.C.Y., Tsao, S.W., Kok, K.H., Jin, D.Y., Chan, K.H., Yuen, K.Y., 2016. Differential cell line susceptibility to the emerging Zika virus: implications for disease pathogenesis, non-vector-borne human transmission and animal reservoirs. Emerg. Microb. Infect. 5, e93. https://doi. org/10.1038/emi.2016.99.

Chant, C., Rybak, M.J., 1995. Quinupristin/dalfopristin (RP 59500): a new streptogramin antibiotic. Ann. Pharmacother. 29, 1022-1027. https://doi.org/10.1177/ 106002809502901013.

Chen, Y., Maguire, T., Marks, R.M., 1996. Demonstration of binding of dengue virus envelope protein to target cells. J. Virol. 70, 8765-8772

Cholo, M.C., Mothiba, M.T., Fourie, B., Anderson, R., 2017. Mechanisms of action and therapeutic efficacies of the lipophilic antimycobacterial agents clofazimine and bedaquiline. J. Antimicrob. Chemother. 72, 338-353. https://doi.org/10.1093/jac/ dkw426.

Crill, W.D., Roehrig, J.T., 2001. Monoclonal antibodies that bind to domain III of dengue virus E glycoprotein are the most efficient blockers of virus adsorption to Vero cells. J. Virol. 75, 7769-7773.

Dai, L., Song, J., Lu, X., Deng, Y.Q., Musyoki, A.M., Cheng, H., Zhang, Y., Yuan, Y., Song, H., Haywood, J., Xiao, H., Yan, J., Shi, Y., Qin, C.F., Qi, J., Gao, G.F., 2016. Structures of the zika virus envelope protein and its complex with a flavivirus broadly protective antibody. Cell Host Microbe 19, 696-704. https://doi.org/10.1016/j.chom.2016.04. 013.

de Gara, C., Taylor, M., Hedges, A., 1982. Assessment of analgesic drugs in soft tissue injuries presenting to an accident and emergency department-a comparison of antrafenine, paracetamol and placebo. Postgrad. Med. J. 58, 489-492.

de Silva, A.M., Rey, F.A., Young, P.R., Hilgenfeld, R., Vasudevan, S.G., 2018. Viral entry and NS1 as potential antiviral drug targets. In: Advances in Experimental Medicine and Biology, pp. 107-113. https://doi.org/10.1007/978-981-10-8727-1_8.

Ebi, K.L., Nealon, J., 2016. Dengue in a changing climate. Environ. Res. 151, 115-123. https://doi.org/10.1016/j.envres.2016.07.026.

Eglen, R.M., Schneider, Gisbert, Bohm, H., Bohm, H.J., Schneider, G., 2000. High throughput screening and virtual screening: entry points to drug discovery. Virtual screen. Bioact. Mol. 10, 59-79.

Erbel, P., Schiering, N., D'Arcy, A., Renatus, M., Kroemer, M., Lim, S.P., Yin, Z., Keller, T.H., Vasudevan, S.G., Hommel, U., 2006. Structural basis for the activation of flaviviral NS3 proteases from dengue and West Nile virus. Nat. Struct. Mol. Biol. 13, 372-373. https://doi.org/10.1038/nsmb1073.

Finlay, A.C., Hobby, G.L., Hochstein, F., Lees, T.M., Lenert, T.F., Means, J.A., P'an, S.Y., Regna, P.P., Routien, J.B., Sobin, B.A., Tate, K.B., Kane, J.H., 1951. Viomycin, a new antibiotic active against mycobacteria. Am. Rev. Tuberc. Pulm. Dis. 63, 1-3.

Flasche, S., Jit, M., Rodríguez-Barraquer, I., Coudeville, L., Recker, M., Koelle, K., Milne, G., Hladish, T.J., Perkins, T.A., Cummings, D.A.T., 2016. The long-term safety, public health impact, and cost-effectiveness of routine vaccination with a recombinant, liveattenuated dengue vaccine (Dengvaxia): a model comparison study. PLoS Med. 13, e1002181. https://doi.org/10.1371/journal.pmed.1002181.

Freel Meyers, C.L., Oberthür, M., Anderson, J.W., Kahne, D., Walsh, C.T., 2003. Initial characterization of novobiocic acid noviosyl transferase activity of NovM in biosynthesis of the antibiotic novobiocin. Biochemistry 42, 4179-4189. https://doi.org/ 10.1021/bi0340088.

Fros, J.J., Liu, W.J., Prow, N.A., Geertsema, C., Ligtenberg, M., Vanlandingham, D.L., Schnettler, E., Vlak, J.M., Suhrbier, A., Khromykh, A.A., Pijlman, G.P., 2010. Chikungunya virus nonstructural protein 2 inhibits type I/II interferon-stimulated JAK-STAT signaling. J. Virol. 84, 10877-10887. https://doi.org/10.1128/JVI. 00949-10.

Fros, J.J., Major, L.D., Scholte, F.E.M., Gardner, J., van Hemert, M.J., Suhrbier, A., Pijlman, G.P., 2015. Chikungunya virus non-structural protein 2-mediated host shutoff disables the unfolded protein response. J. Gen. Virol. 96, 580-589.

Gardner, L.M., Bóta, A., Gangavarapu, K., Kraemer, M.U.G., Grubaugh, N.D., 2018. Inferring the risk factors behind the geographical spread and transmission of Zika in the Americas. PLoS Neglected Trop. Dis. 12. https://doi.org/10.1371/journal.pntd. 0006194.

Garoff, H., Sjoberg, M., Cheng, R.H., 2004. Budding of alphaviruses. Virus Res. 106, 103-116. https://doi.org/10.1016/j.virusres.2004.08.008.

Glasner, D.R., Puerta-Guardo, H., Beatty, P.R., Harris, E., 2018. The good, the bad, and the shocking: the multiple roles of dengue virus nonstructural protein 1 in protection and pathogenesis. Annu. Rev. Virol. 5, 227-253. https://doi.org/10.1146/annurevvirology-101416-041848.

González-Molleda, L., Wang, Y., Yuan, Y., 2012. Potent antiviral activity of topoisomerase I and II inhibitors against Kaposi's sarcoma-associated herpesvirus. Antimicrob. Agents Chemother. 56, 893-902. https://doi.org/10.1128/AAC.05274-11.

Guzman, M.G., Alvarez, M., Halstead, S.B., 2013. Secondary infection as a risk factor for dengue hemorrhagic fever/dengue shock syndrome: an historical perspective and role of antibody-dependent enhancement of infection. Arch. Virol. 158, 1445-1459. https://doi.org/10.1007/s00705-013-1645-3.

Hallengärd, D., Kakoulidou, M., Lulla, A., Kümmerer, B.M., Johansson, D.X., Mutso, M., Lulla, V., Fazakerley, J.K., Roques, P., Le Grand, R., Merits, A., Liljeström, P., 2014. Novel attenuated Chikungunya vaccine candidates elicit protective immunity in C57BL/6 mice. J. Virol. 88, 2858-2866. https://doi.org/10.1128/JVI.03453-13.

Halstead, S.B., 2017. Dengvaxia sensitizes seronegatives to vaccine enhanced disease regardless of age. Vaccine 35, 6355-6358. https://doi.org/10.1016/j.vaccine.2017. 09.089.

Harrison, S.C., 2015. Viral membrane fusion. Virology 479, 498-507. https://doi.org/10. 1016/j.virol.2015.03.043.

Henß, L., Beck, S., Weidner, T., Biedenkopf, N., Sliva, K., Weber, C., Becker, S., Schnierle, B.S., 2016. Suramin is a potent inhibitor of Chikungunya and Ebola virus cell entry.
Virol. J. 13, 149. https://doi.org/10.1186/s12985-016-0607-2.

Iakovlev, V.P., Kaplar-Vuchevats, M., 1994. Cefpiramide-a new cephalosporin antibiotic. Antibiot. i khimioterapiia $=$ Antibiot. chemoterapy [sic] 39, 56-64.

Keam, S.J., Lyseng-Williamson, K.A., Goa, K.L., Korenblat, P.E., Lockey, R.F., Obase, Y., Rovati, G.E., Sampson, A.P., Smith, L.J., Tamura, G., 2003. Pranlukast: a review of its use in the management of asthma. Drugs. https://doi.org/10.2165/00003495200363100-00005.

Kielian, M., Chanel-Vos, C., Liao, M., 2010. Alphavirus entry and membrane fusion. Viruses. https://doi.org/10.3390/v2040796.

Kim, S., Kim, H., Ryu, Y., Lee, J., et al., 2016. Efficacy and safety of modified pranlukast $\left(\right.$ Prakanon $^{\circledast}$ ) compared with pranlukast (Onon $\left.{ }^{\circledast}\right)$ : a randomized, open-label, crossover study. ncbi.nlm.nih.gov 10, 36-45 open respiratory, 2016, U.

Klumpp, K., Crépin, T., 2014. Capsid proteins of enveloped viruses as antiviral drug targets. Curr. Opin. Virol. 5, 63-71. https://doi.org/10.1016/j.coviro.2014.02.002.

Kraus, A.A., Messer, W., Haymore, L.B., De Silva, A.M., 2007. Comparison of plaque- and flow cytometry-based methods for measuring dengue virus neutralization. J. Clin. Microbiol. 45, 3777-3780. https://doi.org/10.1128/JCM.00827-07.

Langedijk, J., 2016. Continuous Innovation in the Drug Life Cycle. Elsevier.

Law, V., Knox, C., Djoumbou, Y., Jewison, T., Guo, A.C., Liu, Y., Maciejewski, A., Arndt, D., Wilson, M., Neveu, V., Tang, A., Gabriel, G., Ly, C., Adamjee, S., Dame, Z.T., Han, B., Zhou, Y., Wishart, D.S., 2014. DrugBank 4.0: shedding new light on drug metabolism. Nucleic Acids Res. 42, D1091-D1097. https://doi.org/10.1093/nar/gkt1068.

Lazear, H.M., Govero, J., Smith, A.M., Platt, D.J., Fernandez, E., Miner, J.J., Diamond, M.S., 2016. A mouse model of zika virus pathogenesis. Cell Host Microbe 19 720-730. https://doi.org/10.1016/j.chom.2016.03.010.

Liang, Q., Luo, Z., Zeng, J., Chen, W., Foo, S., Lee, S., 2016. Zika virus NS4A and NS4B proteins deregulate Akt-mTOR signaling in human fetal neural stem cells to inhibit neurogenesis and induce autophagy. 2016, U. Cell, J.G.-C. stem 19, 663-671 Elsevier.

Lim, S.P., Noble, C.G., Seh, C.C., Soh, T.S., El Sahili, A., Chan, G.K.Y., Lescar, J., Arora, R., Benson, T., Nilar, S., Manjunatha, U., Wan, K.F., Dong, H., Xie, X., Shi, P.-Y., Yokokawa, F., 2016. Potent allosteric dengue virus NS5 polymerase inhibitors: mechanism of action and resistance profiling. PLoS Pathog. 12, e1005737. https://doi. org/10.1371/journal.ppat.1005737.

Liu-Helmersson, J., Quam, M., Wilder-Smith, A., Stenlund, H., Ebi, K., Massad, E., Rocklöv, J., 2016. Climate change and Aedes vectors: 21st century projections for dengue transmission in europe. EBioMedicine 7, 267-277. https://doi.org/10.1016/ j.ebiom.2016.03.046.

López-Camacho, C., Abbink, P., Larocca, R.A., Dejnirattisai, W., Boyd, M., BadamchiZadeh, A., Wallace, Z.R., Doig, J., Sanchez Velazquez, R., Dias Lins Neto, R., F Coelho, D., Chan Kim, Y., Donald, C.L., Owsianka, A., De Lorenzo, G., Kohl, A., Gilbert, S.C., Dorrell, L., Mongkolsapaya, J., Patel, A.H., Screaton, G.R., Barouch, D.H., Hill, A.V.S., Reyes-Sandoval, A., 2018. Rational Zika vaccine design via the modulation of antigen membrane anchors in chimpanzee adenoviral vectors. nature.com 9, 2441.

Low, J.G.H., Ooi, E.E., Vasudevan, S.G., 2017. Current status of dengue therapeutics research and development. J. Infect. Dis. 215, S96-S102. https://doi.org/10.1093/ infdis/jiw423.

Ma, D.-L., Chan, D.S.-H., Leung, C.-H., 2013. Drug repositioning by structure-based virtual screening. Chem. Soc. Rev. 42, 2130-2141. https://doi.org/10.1039/ C2CS35357A.

Ma, L., Jones, C.T., Groesch, T.D., Kuhn, R.J., Post, C.B., 2004. Solution structure of dengue virus capsid protein reveals another fold. Proc. Natl. Acad. Sci. United States Am. 101, 3414-3419. https://doi.org/10.1073/pnas.0305892101.

Makhatadze, G.I., Privalov, P.L., 1995. Energetics of protein structure. Adv. Protein Chem. 47, 307-425. https://doi.org/10.1016/S0065-3233(08)60548-3.

Marsh, M., Pelchen-Matthews, A., 1993. Entry of animal viruses into cells. Rev. Med. Virol. 3, 173-185. https://doi.org/10.1002/rmv.1980030307.

Más, V., Melero, J.A., 2013. Entry of enveloped viruses into host cells: membrane fusion. In: Mateu, M.G. (Ed.), Structure and Physics of Viruses: an Integrated Textbook. Springer Netherlands, Dordrecht, pp. 467-487. https://doi.org/10.1007/978-94007-6552-8_16.

Mayer, S.V., Tesh, R.B., Vasilakis, N., 2017. The emergence of arthropod-borne viral diseases: a global prospective on dengue, chikungunya and zika fevers. Acta Trop. 166, 155-163. https://doi.org/10.1016/j.actatropica.2016.11.020.

Mazzola, E.P., Melin, J.A., Wayland, L.G., 1980. 13C-NMR spectroscopy of three tetracycline antibiotics: minocycline hydrochloride, meclocycline, and rolitetracycline. J. Pharm. Sci. 69, 229-230. https://doi.org/10.1002/jps.2600690236.

Mehndiratta, M.M., Wadhai, S.A., Tyagi, B.K., Gulati, N.S., Sinha, M., 2016. Drug repositioning. Int. J. Epilepsy 3, 91-94. https://doi.org/10.1016/j.ijep.2016.09.002

Mishra, P., Kumar, A., Mamidi, P., Kumar, S., Basantray, I., Saswat, T., Das, I., Nayak, T.K., Chattopadhyay, Subhasis, Subudhi, B.B., Chattopadhyay, Soma, 2016. Inhibition of chikungunya virus replication by 1-[(2-Methylbenzimidazol-1-yl) methyl]-2-oxo-indolin-3-ylidene] amino] thiourea(MBZM-N-IBT). Sci. Rep. 6, 20122. https://doi.org/10.1038/srep20122.

Modis, Y., Ogata, S., Clements, D., Harrison, S.C., 2004. Structure of the dengue virus envelope protein after membrane fusion. Nature 427, 313-319. https://doi.org/10. 1038/nature02165.

Montes-Grajales, D., Bernardes, G.J.L., Olivero-Verbel, J., 2016. Urban endocrine disruptors targeting breast cancer proteins. Chem. Res. Toxicol. 29, 150-161.

Montes-Grajales, D., Olivero-Verbel, J., 2013. Computer-aided identification of novel protein targets of bisphenol A. Toxicol. Lett. 222, 312-320. https://doi.org/10.1016/ j.toxlet.2013.08.010.

Montes-Grajales, D., Olivero-Verbel, J., Cabarcas-Montalvo, M., 2013. DDT and derivatives may target insulin pathway proteins. J. Brazilian Chem. Soc.

Montoya, M., Collins, M., Dejnirattisai, W., Katzelnick, L.C., Puerta-Guardo, H., Jadi, R., Schildhauer, S., Supasa, P., Vasanawathana, S., Malasit, P., Mongkolsapaya, J., De 
Silva, A.D., Tissera, H., Balmaseda, A., Screaton, G., De Silva, A.M., Harris, E., 2018. Longitudinal analysis of antibody cross-neutralization following zika virus and dengue virus infection in Asia and the Americas. J. Infect. Dis. 218, 536-545. https:// doi.org/10.1093/infdis/jiy164.

Morris, G.M., Huey, R., Lindstrom, W., Sanner, M.F., Belew, R.K., Goodsell, D.S., Olson, A.J., 2009. AutoDock4 and AutoDockTools4: automated docking with selective receptor flexibility. J. Comput. Chem. 30, 2785-2791. https://doi.org/10.1002/jcc. 21256.

Nolting, A., Costa, T.D., Rand, K.H., Derendorf, H., 1996. Pharmacokinetic-pharmacodynamic modeling of the antibiotic effect of piperacillin in vitro. Pharm. Res. 13, 91-96. https://doi.org/10.1023/A:1016085402278.

O'Boyle, N.M., Banck, M., James, C.A., Morley, C., Vandermeersch, T., Hutchison, G.R. 2011. Open Babel: an open chemical toolbox. J. Cheminf. 3, 33. https://doi.org/10. 1186/1758-2946-3-33.

O'Connor, K.A., Roth, B.L., 2005. Finding new tricks for old drugs: an efficient route for public-sector drug discovery. Nat. Rev. Drug Discov. 4, 1005-1014. https://doi.org/ $10.1038 /$ nrd1900.

Oliveira, A.F., Teixeira, R.R., Oliveira, A.S., Souza, A.P., Silva, M.L., Paula, S.O., 2017. Potential antivirals: natural products targeting replication enzymes of dengue and chikungunya viruses. Mol. https://doi.org/10.3390/molecules22030505.

Oliveira, E.R.A., Mohana-Borges, R., de Alencastro, R.B., Horta, B.A.C., 2017. The flavivirus capsid protein: structure, function and perspectives towards drug design. Virus Res. 227, 115-123. https://doi.org/10.1016/j.virusres.2016.10.005.

Patil, R., Das, S., Stanley, A., Yadav, L., Sudhakar, A., Varma, A.K., 2010. Optimized hydrophobic interactions and hydrogen bonding at the target-ligand interface leads the pathways of drug-designing. PLoS One 5, e12029. https://doi.org/10.1371/ journal.pone.0012029.

Pfaller, M.A., Flamm, R.K., Duncan, L.R., Mendes, R.E., Jones, R.N., Sader, H.S., 2017. Antimicrobial activity of tigecycline and cefoperazone/sulbactam tested against 18,386 Gram-negative organisms from Europe and the Asia-Pacific region (2013-2014). Diagn. Microbiol. Infect. Dis. 88, 177-183. https://doi.org/10.1016/j. diagmicrobio.2017.02.020.

Pu, S.Y., Xiao, F., Schor, S., Bekerman, E., Zanini, F., Barouch-Bentov, R., Nagamine, C.M., Einav, S., 2018. Feasibility and biological rationale of repurposing sunitinib and erlotinib for dengue treatment. Antivir. Res. 155, 67-75. https://doi.org/10.1016/j. antiviral.2018.05.001.

Puerta-Guardo, H., Glasner, D.R., Espinosa, D.A., Biering, S.B., Patana, M., Ratnasiri, K., Wang, C., Beatty, P.R., Harris, E., 2019a. Flavivirus NS1 triggers tissue-specific vascular endothelial dysfunction reflecting disease tropism. Cell Rep. 26, 1598-1613. https://doi.org/10.1016/J.CELREP.2019.01.036. e8.

Puerta-Guardo, H., Tabata, T., Petitt, M., Dimitrova, M., Glasner, D.R., Pereira, L., Harris, E., 2019b. Zika virus non-structural protein 1 disrupts glycosaminoglycans and causes permeability in developing human placentas. J. Infect. Dis. https://doi.org/ 10.1093/infdis/jiz331.

Pushpakom, S., Iorio, F., Eyers, P.A., Escott, K.J., Hopper, S., Wells, A., Doig, A. Guilliams, T., Latimer, J., McNamee, C., Norris, A., Sanseau, P., Cavalla, D., Pirmohamed, M., 2018. Drug repurposing: progress, challenges and recommendations. Nat. Rev. Drug Discov. https://doi.org/10.1038/nrd.2018.168.

R Core Team, 2016. A Language and Environment for Statistical Computing. R Foundation for statistical computing, Vienna, Austria 2015.

Rodenhuis-Zybert, I.A., Wilschut, J., Smit, J.M., 2010. Dengue virus life cycle: viral and host factors modulating infectivity. Cell. Mol. Life Sci. 67, 2773-2786. https://doi. org/10.1007/s00018-010-0357-z.

Roy, C.J., Adams, A.P., Wang, E., Plante, K., Gorchakov, R., Seymour, R.L., VinetOliphant, H., Weaver, S.C., 2014. Chikungunya vaccine candidate is highly attenuated and protects nonhuman primates against telemetrically monitored disease following a single dose. J. Infect. Dis. 209, 1891-1899.

Samsa, Marcelo M., Mondotte, J.A., Iglesias, N.G., Assunção-Miranda, I., Barbosa-Lima, G., Da Poian, A.T., Bozza, P.T., Gamarnik, A.V., 2009. Dengue virus capsid protein usurps lipid droplets for viral particle formation. PLoS Pathog. https://doi.org/10. 1371/journal.ppat.1000632.

Samsa, Marcelo M., Mondotte, J.A., Iglesias, N.G., Assunção-Miranda, I., Barbosa-Lima, G., Da Poian, A.T., Bozza, P.T., Gamarnik, A.V., 2009. Dengue virus capsid protein usurps lipid droplets for viral particle formation. PLoS Pathog. 5, e1000632. https:// doi.org/10.1371/journal.ppat.1000632.

Scherwitzl, I., Mongkolsapaja, J., Screaton, G., 2017. Recent advances in human flavivirus vaccines. Curr. Opin. Virol. 23, 95-101. https://doi.org/10.1016/j.coviro.2017.04. 002.

Schneider, M., Korzeniewski, N., Merkle, K., Schüler, J., Grüllich, C., Hadaschik, B., Hohenfellner, M., Duensing, S., 2015. The tyrosine kinase inhibitor nilotinib has antineoplastic activity in prostate cancer cells but up-regulates the ERK survival signal-implications for targeted therapies1Equal contributions. Urol. Oncol. Semin. Orig. Investig. 33https://doi.org/10.1016/j.urolonc.2014.06.001. 72.e1-72.e7.

Seeliger, D., de Groot, B.L., 2010. Ligand docking and binding site analysis with PyMOL and Autodock/Vina. J. Comput. Aided Mol. Des. 24, 417-422. https://doi.org/10. 1007/s10822-010-9352-6.

Sekiguchi, J., Shuman, S., 1997. Novobiocin inhibits vaccinia virus replication by blocking virus assembly. Virology 235, 129-137. https://doi.org/10.1006/viro.1997. 8684.

Smalley, C., Erasmus, J.H., Chesson, C.B., Beasley, D.W.C., 2016. Status of research and development of vaccines for chikungunya. Vaccine 34, 2976-2981. https://doi.org/ 10.1016/j.vaccine.2016.03.076.

Soto-Acosta, R., Mosso, C., Cervantes-Salazar, M., Puerta-Guardo, H., Medina, F., Favari, L., Ludert, J.E., Del Angel, R.M., 2013. The increase in cholesterol levels at early stages after dengue virus infection correlates with an augment in LDL particle uptake and HMG-CoA reductase activity. Virology 442, 132-147. https://doi.org/10.1016/j. virol.2013.04.003.

Stein, C.A., LaRocca, R.V., Thomas, R., McAtee, N., Myers, C.E., 1989. Suramin: an anticancer drug with a unique mechanism of action. J. Clin. Oncol. 7.

Subudhi, B.B., Chattopadhyay, S., Mishra, P., Kumar, A., 2018. Current strategies for inhibition of Chikungunya infection. Viruses. https://doi.org/10.3390/v10050235.

Tfelt-Hansen, P.C., Koehler, P.J., 2008. History of the use of ergotamine and dihydroergotamine in migraine from 1906 and onward. Cephalalgia 28, 877-886. https://doi.org/10.1111/j.1468-2982.2008.01578.x.

Tomlinson, S.M., Malmstrom, R.D., Russo, A., Mueller, N., Pang, Y.-P., Watowich, S.J., 2009. Structure-based discovery of dengue virus protease inhibitors. Antivir. Res. 82, 110-114. https://doi.org/10.1016/j.antiviral.2009.02.190.

Trott, O., Olson, A.J., 2010. AutoDock Vina: improving the speed and accuracy of docking with a new scoring function, efficient optimization, and multithreading. J. Comput. Chem. 31, 455-461. https://doi.org/10.1002/jcc.21334.

Villegas, L.E.M., Campolina, T.B., Barnabe, N.R., Orfano, A.S., Chaves, B.A., Norris, D.E., Pimenta, P.F.P., Secundino, N.F.C., 2018. Zika virus infection modulates the bacterial diversity associated with Aedes aegypti as revealed by metagenomic analysis. PLoS One 13, e0190352. https://doi.org/10.1371/journal.pone.0190352.

Voss, J.E., Vaney, M.-C., Duquerroy, S., Vonrhein, C., Girard-Blanc, C., Crublet, E., Thompson, A., Bricogne, G., Rey, F.A., 2010. Glycoprotein organization of Chikungunya virus particles revealed by X-ray crystallography. Nature 468, 709-712. https://doi.org/10.1038/nature09555.

Walker, T., Jeffries, C.L., Mansfield, K.L., Johnson, N., 2014. Mosquito cell lines: history, isolation, availability and application to assess the threat of arboviral transmission in the United Kingdom. Parasites Vectors 7, 382. https://doi.org/10.1186/1756-33057-382.

Warnes, G.R., Bolker, B., Bonebakker, L., Gentleman, R., Huber, W., Liaw, A., Lumley, T., Maechler, M., Magnusson, A., Moeller, S., 2009. Gplots: Various R Programming Tools for Plotting Data. R Packag. version.

Weaver, S.C., 2014. Arrival of chikungunya virus in the new world: prospects for spread and impact on public health. PLoS Neglected Trop. Dis. 8, e2921. https://doi.org/10. 1371/journal.pntd.0002921.

Weber, C., Berberich, E., von Rhein, C., Henß, L., Hildt, E., Schnierle, B.S., 2017. Identification of functional determinants in the chikungunya virus E2 protein. PLoS Neglected Trop. Dis. 11, e0005318. https://doi.org/10.1371/journal.pntd.0005318.

Whitehead, S.S., Subbarao, K., 2017. Which dengue vaccine approach is the most promising, and should we Be concerned about enhanced disease after vaccination?: the risks of incomplete immunity to dengue virus revealed by vaccination. Cold Spring Harb. Perspect. Biol. https://doi.org/10.1101/cshperspect.a028811.

Wolber, G., Langer, T., 2005. LigandScout: 3-D pharmacophores derived from proteinbound ligands and their use as virtual screening filters. J. Chem. Inf. Model. 45, 160-169. https://doi.org/10.1021/ci049885e.

Wolf, D., Djian, E., Beider, K., Shimoni, A., Nagler, A., 2012. Nilotinib exhibits an in vitro antiviral activity against human cytomegalovirus (HCMV): potential clinical applications. Am. Soc. Hematol. 120, 4666.

World Health Organization, 2018. Zika virus. [WWW Document]. https://www.who.int/ news-room/fact-sheets/detail/zika-virus accessed 7.10.19.

World Health Organization, 2017. Chikungunya. [WWW Document]. https://www.who. int/emergencies/diseases/chikungunya/en/.

World Health Organization, 2016. Facsheet dengue and severe dengue. [WWW Document]. July 2016. http://www.who.int/mediacentre/factsheets/fs117/en/.

Xie, X., Zou, J., Wang, Q.Y., Shi, P.Y., 2015. Targeting dengue virus NS4B protein for drug discovery. Antivir. Res. https://doi.org/10.1016/j.antiviral.2015.03.007.

Yap, T.L., Xu, T., Chen, Y.-L., Malet, H., Egloff, M.-P., Canard, B., Vasudevan, S.G., Lescar, J., 2007. Crystal structure of the dengue virus RNA-dependent RNA polymerase catalytic domain at 1.85-angstrom resolution. J. Virol. 81, 4753-4765. https://doi. org/10.1128/JVI.02283-06.

Young, T., Abel, R., Kim, B., Berne, B.J., Friesner, R.A., 2007. Motifs for molecular recognition exploiting hydrophobic enclosure in protein-ligand binding. Proc. Natl. Acad. Sci. 104, 808-813. https://doi.org/10.1073/pnas.0610202104.

Zhang, J., Li, C., Lin, Y., Shao, Y., Li, S., 2017. Computational drug repositioning using collaborative filtering via multi-source fusion. Expert Syst. Appl. https://doi.org/10. 1016/j.eswa.2017.05.004.

Zhang, X., Jia, R., Shen, H., Wang, M., Yin, Z., Cheng, A., 2017. Structures and functions of the envelope glycoprotein in flavivirus infections. Viruses 9, 338. https://doi.org/ 10.3390/v9110338.

Zuckerman, J.M., Tunkel, A.R., 1994. Itraconazole: a new triazole antifungal agent. Infect. Control Hosp. Epidemiol. 15, 397-410. https://doi.org/10.2307/30145593. 